Article

\title{
Mediating Effects of Cohesion Policy and Institutional Quality on Convergence between EU Regions: An Examination Based on a Conditional Beta-Convergence Model with a 3-Way Multiplicative Term
}

\author{
Mindaugas Butkus ${ }^{\circledR}$, Alma Mačiulytè-Šniukienė ${ }^{\circledR}$ and Kristina Matuzevičiūtè *(i) \\ Institute of Regional Development, Šiauliai University, 76351 Šiauliai, Lithuania; mindaugas.butkus@su.lt (M.B.); \\ alma.maciulyte-sniukiene@su.lt (A.M.-̌̌.) \\ * Correspondence: kristina.matuzeviciute@su.lt; Tel.: +370-41595885
}

Received: 23 February 2020; Accepted: 6 April 2020; Published: 9 April 2020

check for updates

\begin{abstract}
The paper contributes to the existing literature on the EU's Cohesion Policy outcomes by extending the conditional beta-convergence model with a 3-way multiplicative term to examine the mediating effects of the Cohesion Policy, institutional quality, and their interaction on regional convergence. The empirical analysis based on conditional slope coefficients and conditional standard errors provides evidence that both the mediating factors under consideration contribute positively to boosting regional convergence in the EU at the NUTS 2 and 3 disaggregation level, but with much bigger success over the 2007-2013 programming period compared to the previous one. Moreover, Cohesion Policy and institutional quality act as substituting rather than complementary mediating factors.
\end{abstract}

Keywords: Cohesion Policy; institutional quality; convergence; multiplicative term; conditional effect

\section{Introduction}

The main objective of the EU's Cohesion Policy $(\mathrm{CP})$ is to strengthen regional cohesion, in particular by targeting less developed regions, aiming to reduce disparities within the EU. The EU allocates over $30 \%$ of the overall budget to achieve the goals of the $\mathrm{CP}$. The studies that examined the effectiveness of the $\mathrm{CP}$ over the last two programming periods considered various outcomes of this policy: employment [1-3], productivity [4-6], but mostly economic growth ([3,6-12], etc.), even though convergence is the ultimate goal of the CP.

A few studies $[9,12-14]$ that analyse the convergence outcomes of the CP apply a conditional beta-convergence model augmented by cohesion payments (commitments, spending, transfers, expenditures, and investments) as a growth factor while controlling the initial level of development or, in a dynamic setting, the level of development over the previous period. Reference [15] used a stochastic endogenous growth model evaluating the impact of EU accession on convergence, assuming that structural and cohesion funds speed up the convergence process. Reference [16] employed a feasible general least squares estimator with seemingly unrelated regression weights to identify a functional form of the relationship between the structural funds and the evolution of regional disparities across countries over time, and the nature of diminishing returns at a particular threshold level of funding intensity. Results of [14-16] showed positive but size-varying convergence outcomes of the $\mathrm{CP}$; meanwhile, $[9,12,13]$ have found that although $\mathrm{CP}$ had a positive effect on growth, an impact on convergence was not significant. 
The ambiguous results of previous research (see Appendix A) incite much debate in political and scientific areas about regional conditions that could lead to the heterogeneous outcomes of the $\mathrm{CP}$. It has already been ascertained that institutional quality is mediating the effect of the $\mathrm{CP}$ on growth [5,16-19] and that institutions can be considered as a factor that connects or at least influences all other factors that mediate outcomes of the CP [16,20-25]. However, no research examines how institutions shape the convergence outcomes of the $\mathrm{CP}$.

Most of the previous studies that apply conditional beta-convergence model examine the outcomes of the $\mathrm{CP}$ by augmenting the specification with cohesion payments or eligibility status as a growth factor. Some specifications interact the $\mathrm{CP}$ variable with factors that are considered as the mediating growth outcomes of the $\mathrm{CP}$. Research that interacts $\mathrm{CP}$ with the initial level of development $[7,8,13,26]$ uses this multiplicative term to examine how the level of development mediates the effect that $\mathrm{CP}$ has on growth. Surprisingly no research interprets this multiplicative term in a way to examine how $\mathrm{CP}$ mediates the relationship between the initial level of development and growth, i.e., regional convergence. Furthermore, no research interacts $\mathrm{CP}$, the initial level of development, and institutional quality to examine the mediating effects of the $\mathrm{CP}$, institutional quality, and their interaction on convergence. Moreover, research that uses model specifications with the interaction term between interval/ratio variables rarely (except for $[8,18]$ ) recognises that the estimated marginal effect (the slope coefficient), as well as its significance, is conditional, i.e., it depends on the value of the mediating factor. It means there could be a range of values for the mediating factor over which the estimated marginal effect of the $\mathrm{CP}$ is positive and the range over which this effect is negative. The same applies to the significance of the estimated marginal effect of the CP.

Our paper aims to contribute the existing literature on the outcomes of the $\mathrm{CP}$ in a few ways: (i) it proposes to extend a conditional beta-convergence model with a 3-way multiplicative term in order to examine not only the mediating effects on the growth outcomes of the $\mathrm{CP}$ but also to analyse the mediating effects on the convergence outcomes of the CP; (ii) following [27], we test our hypotheses, realising that they are conditional in nature by computing the meaningful marginal effects and their standard errors; (iii) since growth is directly related to the marginal productivity of labour, and CP payments are intended to boost productivity in the least developed EU areas and, in turn, regional growth and convergence, our paper examines the outcomes of the CP not only in terms of per capita GDP but also in terms of productivity; (iv) since most of the studies dealing with effectiveness of the $\mathrm{CP}$ have been carried out at the country as well as NUTS 1 and 2 disaggregation level (excluding a few at NUTS $3[28,29])$, and all studies that examine convergence outcomes of the CP [9,12-16] focus solely on countries and NUTS 1 and 2 disaggregation, our paper examines the growth and convergence outcomes of the $\mathrm{CP}$ at the NUTS 3 level as well.

The rest of the paper is organized as follows: Section 2 presents a literature review. Section 3 discusses the research model. Section 4 presents the estimation results and discussion. The last section concludes the paper.

\section{Literature Review}

There is a wide range of studies that investigate outcomes of the CP over the 2000-2006 and 2007-2013 programming periods (see Appendix A). However, most of them focus on one outcome, and it is not a convergence even though one being the main aim of the CP. Authors mainly investigated the impact of the $\mathrm{CP}$ on regional growth (see Appendix $\mathrm{A}$ ). In order to evaluate the effectiveness of the $\mathrm{CP}$, it is reasonable to examine not only economic growth but also the productivity growth and convergence outcomes of the $\mathrm{CP}$.

In principle, economic growth is directly related to the marginal productivity of labour. Both $[30,31]$ neo-classical and $[32,33]$ endogenous growth models state that capital, labour, and the level of technology are the essential inputs for growth. According to neoclassical theory, as the amount of capital rises, the marginal product of labour increases due to exogenous technological progress. Reference [32], by augmenting their growth model with human capital, also emphasised the importance of innovations 
for output per hour growth. Moreover, this theory drew attention to possible dependence between the growth effects of endogenous factors and the institutional environment. Given that $\mathrm{CP}$ payments are allocated to the projects intended to create a productive environment, enhance human resources, build infrastructure, etc., CP should, theoretically, raise the amount of physical and human capital, as well as productivity, which would lead to the economic growth of the support beneficiaries.

Since $\mathrm{CP}$ investment can be treated as a public investment, the impact on productivity and growth also can be explained via influence on boosting private capital. Public investments directed to the development of infrastructure, as well as an increased supply of public services and goods, create a secured and favourable environment for private investments and lead to lower costs of investment [34]. Moreover, an increase in the demand for public services and goods raises expectations in revenue and profit of the private sector and may encourage private investment. Investment in transport infrastructure reduces transportation costs and, according to new economic geography theory [35], through this channel influences economic growth. According to [36], these forces influence the geographical concentration of economic activities and the productive advantage.

Reference [7] argued that if CP payments are transferred to capital-scarce regions, less developed economies in the short-run should experience faster economic growth compared to more developed ones and, in the long-run, the growth rates become similar due to decreasing return on capital investments. According to this approach, exogenously determined technological development increases the steady-state regional growth rate. Since CP is oriented to distribute support to the less developed EU's regions, the economic growth of beneficiaries has to burst regional convergence if lagging regions grow faster.

Summarising the theoretical considerations on the outcomes of the $\mathrm{CP}$, it can be argued that $\mathrm{CP}$ payments may boost productivity, and this, in turn, could lead to regional economic growth. If less developed regions grow faster compared with the more developed ones, this promotes convergence (CP payments $\rightarrow$ Productivity growth $\rightarrow$ Economic growth $\rightarrow$ Convergence).

Only a few studies $[4-6,15,37]$ evaluated the productivity outcomes of the CP. However, these studies do not allow generalising on $\mathrm{CP}$ outcomes since the evaluation results are ambiguous. According to $[4,15]$ findings, $C P$ positively influenced productivity growth. Reference [37] revealed that $\mathrm{CP}$ has an insignificant impact on productivity. Reference [5] found the contrary results: Distribution of CP funds in total (covering Germany, Spain, France, Italy, and the UK) is negatively and significantly related to regional productivity growth. However, the heterogeneous results were obtained when investigating a relationship in a separate country. The relationship between the distribution of regional funding and productivity in Germany is negative and significant; in Spain and Italy-negative and insignificant; and in the UK-positive but insignificant. Authors revealed that differences in outcomes depend on the political behaviour of the region. According to findings by [6], CP may affect regional productivity positively or negatively, depending on the intervention area.

The convergence outcomes of the $\mathrm{CP}$ over the two last programming periods have been investigated just by a few studies, and neither of them cover the whole previous programming period. Whereas References [14-16] revealed a positive effect, References $[9,12,13]$ revealed no effect of the CP on the convergence between EU countries and NUTS 2 regions, leaving open the question whether it is the case between NUTS 3 regions as well. Moreover, a study by [16] revealed that outcomes of the CP might depend on some conditioning factors. However, previous studies rarely evaluate conditioning factors. Nevertheless, the variety of these factors is relatively huge.

Previous research revealed that the outcomes of the CP depend on human capital accumulated in the region or the country [16,17], economic openness [16], institutional quality and political behaviour [5, 16-19,38], territorial capital/conditions [29,39], ethnic segregation [40], innovation level [41], the degree of urbanisation, and distance from main urban agglomerates [11]. All these factors are interrelated. Institutional quality can be considered as a factor that connects or at least influences all these factors (see Table 1). 
Table 1. Nexus between outcomes of the Cohesion Policy (CP), conditioning factors, and institutional quality.

\begin{tabular}{|c|c|c|}
\hline $\begin{array}{l}\text { Conditioning } \\
\text { Factor }\end{array}$ & Effect on Outcomes of the CP & Relation with Institutional Quality (IQ) \\
\hline \multirow{2}{*}{ 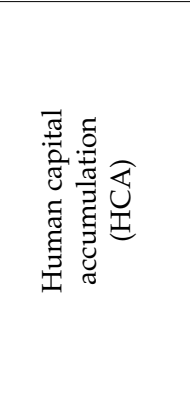 } & \multirow{2}{*}{$\begin{array}{l}\text { Higher HCA, which is related to a higher } \\
\text { level of education in regions, is associated } \\
\text { with a higher attraction of CP investment, } \\
\text { more efficient allocation and utilisation. } \\
\text { HCA leads to positive outcomes of the } \\
\text { CP }[7,16,17]\end{array}$} & $\begin{array}{l}\text { Groups with high cognitive skills tend to } \\
\text { build better institutions, characterised by a } \\
\text { lower degree of corruption, higher level of } \\
\text { property rights and better legal and political } \\
\text { environment [20] }\end{array}$ \\
\hline & & $\begin{array}{l}\text { IQ determines HCA via impact on the } \\
\text { educational sector size, available educational } \\
\text { infrastructure, a condition that allows using } \\
\text { knowledge effectively. HC functions more } \\
\text { efficiently and generates higher education } \\
\text { returns in areas with better institutions }[42,43]\end{array}$ \\
\hline \multirow{3}{*}{ 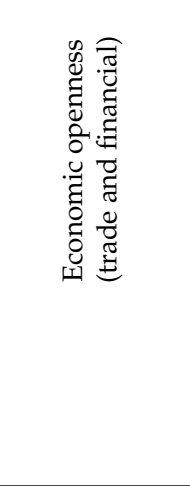 } & $\begin{array}{l}\text { The positive outcomes of the } \mathrm{CP} \text { are } \\
\text { higher in economies that are more } \\
\text { open [16] }\end{array}$ & $\begin{array}{l}\text { Better IQ leads to higher intensity of } \\
\text { international trade }[21,25,44]\end{array}$ \\
\hline & $\begin{array}{l}\text { Low level of trade openness related to } \\
\text { trade barriers, which cause an inefficient } \\
\text { allocation of resources (including CP } \\
\text { investments) and vice versa [45] }\end{array}$ & $\begin{array}{l}\text { Low level of IQ causes trade barriers, } \\
\text { determines lack of enforcement of contacts, } \\
\text { increases costs and risks of trading abroad, } \\
\text { i.e., raises insecurity. Insecurity may prevent } \\
\text { trade even though it offers potential mutual } \\
\text { gains }[21,46]\end{array}$ \\
\hline & $\begin{array}{l}\text { Inward FDI flows attract advanced } \\
\text { foreign technology and innovative } \\
\text { managerial skills. This, in turn, leads to a } \\
\text { better distribution of CP support [47] }\end{array}$ & $\begin{array}{l}\text { Better IQ causes higher inward FDI flows } \\
\text { forming a favourable environment and a } \\
\text { flexible local government decision-making } \\
\text { system }[21,23,48,49]\end{array}$ \\
\hline 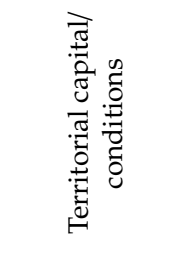 & $\begin{array}{l}\text { The growth outcomes of } \mathrm{CP} \text { are much } \\
\text { more significant in more developed } \\
\text { regions and more endowed with } \\
\text { territorial capital: market potential, } \\
\text { infrastructure, tourists' accommodation } \\
\text { facilities, stock of private capital, } \\
\text { etc. }[29,39]\end{array}$ & $\begin{array}{l}\text { Institutions affect regions' territorial capital } \\
\text { (conditions) due to the influence on } \\
\text { demographics and labour market [50], } \\
\text { infrastructure development, human capital } \\
\text { development [42,43], entrepreneurship and } \\
\text { innovation politics [24], stock of private } \\
\text { capital [51], etc. }\end{array}$ \\
\hline 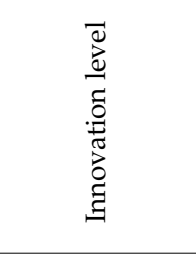 & $\begin{array}{l}\text { CP payments are higher in regions with a } \\
\text { higher level of R\&D investment } \\
\text { (innovative capacity) }[7,41]\end{array}$ & $\begin{array}{l}\text { Institutions may influence the development of } \\
\text { innovation due to a favourable environment } \\
\text { and support system, as well as via supporting } \\
\text { entrepreneurship and this, in turn, spurs } \\
\text { innovations [24]. Corruption has a substantial } \\
\text { negative impact on the quantity, quality, and } \\
\text { efficiency of firms' innovation [22] }\end{array}$ \\
\hline 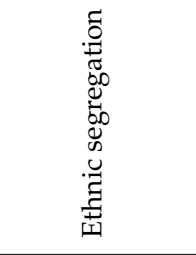 & $\begin{array}{l}\text { When the region belongs to territory with } \\
\text { separated ethnic groups to adopt } \mathrm{CP} \text { and } \\
\text { reduce disparities is more complicated. } \\
\text { The positive effects of CP payments are } \\
\text { smaller in those regions [16] }\end{array}$ & $\begin{array}{l}\text { Ethnic segregation negatively affects IQ. } \\
\text { Ethnic groups may decide to vote for } \\
\text { politicians that belong to their ethnic group } \\
\text { regardless of their competence [ } 52] \text {. A central } \\
\text { or local government may direct resources not } \\
\text { to productive public goods and governance } \\
\text { but to support segregated regions [ } 40]\end{array}$ \\
\hline 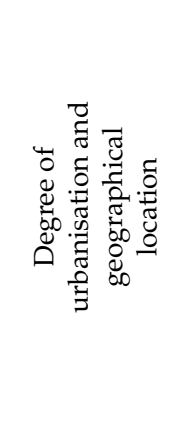 & $\begin{array}{l}\text { Rural areas characterised as territories } \\
\text { with lower real estate prices, living and } \\
\text { labour costs comparing with urbanised } \\
\text { areas. If rural territories are close to city } \\
\text { centres, they can be more attractive for } \\
\text { business and individuals. They benefit } \\
\text { from living or doing business in a rural } \\
\text { area. At the same time, they use the } \\
\text { infrastructure of urban agglomerates. } \\
\text { Regions, which have these characteristics, } \\
\text { can benefit more through CP [11] }\end{array}$ & $\begin{array}{l}\text { Institutions play a crucial role in allocating } \\
\text { national resources, the retribution of national } \\
\text { income and support between regions. If the } \\
\text { country has a high level of democracy, a low } \\
\text { level of corruption, resources will be } \\
\text { distributed more effectively. High managerial } \\
\text { abilities of local government and } \\
\text { representatives to a national assembly ensure } \\
\text { better services for their regions, improved } \\
\text { road and telecommunication system linking } \\
\text { cities to markets, and better access to national } \\
\text { capital markets [53] }\end{array}$ \\
\hline
\end{tabular}


The relationships provided in Table 1 allow us to argue that institutional quality can be considered as the main factor conditioning (hindering or fostering) the outcomes of the CP. This conclusion is in line with the approaches of $[16,19]$. Institutional quality can affect the outcomes of the CP indirectly (IQ $\rightarrow$ other conditioning factors $\rightarrow$ outcomes of the $\mathrm{CP}$ ) and directly (IQ $\rightarrow$ outcomes of the $\mathrm{CP}$ ).

Explaining the role of institutions, we can argue that they are related to the managerial abilities of the local governments $[18,19,54]$, which affect the intensity of CP payments as well as their distribution. If the funds are allocated to productive projects, the return will be higher compared with allocation to unproductive projects. The relationship between $\mathrm{CP}$ implementation and political behaviour is explained by collective action theory [55]. The basic idea is that "regional stakeholders are interested in collective action for investments in local common goods because these provide returns on a territorial basis, excluding competitors located elsewhere, and then providing a competitive advantage" [5]. In order to attract more $\mathrm{CP}$ investments into the region, stakeholders may create political coalitions and take advantage of this opportunity for additional funding. However, it can negatively influence the outcome of the $\mathrm{CP}$ since investments can be allocated to projects that are not the most productive.

The mediating effect of institutional quality on the outcomes of $\mathrm{CP}$ commitments may also occur due to the corruption schemes that are related to the moral hazard phenomenon. More corrupt countries may gain less from CP, since (i) SF and CF support can be distributed to entities whom it does not belong, but that are involved in corruption schemes; and (ii) countries may not invest in lagging regions in order to preserve a low level of prosperity for future regional support [56]. Usually, the entities most in need of support have no established lobbies and have no cash for bribes [57]. In this way, support is given to entities that could carry out the projects themselves, which results in crowding out private investment. This, in turn, leads to the inefficiency of the $\mathrm{CP}$.

\section{Methodology}

To discuss our model, we will start with a classical model used to examine conditional beta-convergence:

$$
g r_{i, t}=\alpha+\beta \cdot \ln \left(Y_{i, t-1}\right)+c_{j} \cdot \boldsymbol{C}_{j, i, t}+\mu_{i}+\varphi_{t}+\varepsilon_{i, t}
$$

where a dependent variable, i.e., $g r_{i, t}$, is the annual growth rate of $Y$ for a cross-sectional unit $i$ over the period $t . Y_{i, t-1}$ is the level of $Y$ over the previous period, $C_{j, i, t}$ is a set of controls usually included in growth equations. $j$ represents the $j$-th control variable. $\mu_{i}$ are time-invariant effects, while $\varphi_{t}$ represents the time effects, and $\varepsilon_{i, t}$ is the idiosyncratic error term. $\alpha, \beta$, and $c_{j}$ are parameters to be estimated. Estimated significant and negative $\beta$ would indicate that conditional beta-convergence is present between $i$ over the period under consideration.

While examining the outcomes of the $\mathrm{CP}$, it is conventional to augment Equation (1) with a variable that proxy the $\mathrm{CP}$ intervention $[6,9,41]$. In some studies, the variable of the $\mathrm{CP}$ is interacted with a factor that is assumed to be mediating the outcomes of the CP. References $[18,19,38]$ have interacted the $\mathrm{CP}$ with the institutional quality as a factor that may affect the transformation of Cohesion investments into growth. Reference [14] have interacted a variable of cohesion investment intensity with itself, i.e., they used the squared term of cohesion investment intensity to test whether the marginal returns of cohesion investment are diminishing. Researchers also use other multiplicative terms in a specification of a beta-convergence model: References $[10,58]$ interacted cohesion payments intensity (intensity squared and intensity cubic) with the treatment dummy in order to estimate different non-linear specifications of the relationship between the outcome and the forcing variable. Reference [14] have interacted the assignment to the Objective 1 status and the EU funds per capita, examining whether the Objective 1 status increases the impact of the funds.

In the research mentioned above, the specifications of the conditional beta-convergence models allow examining just the growth outcomes of the $\mathrm{CP}$ and to interpret that if the initial level of the development is already controlled in the specification; the estimated positive coefficient on the $\mathrm{CP}$ variable shows an additional growth impulse induced by $\mathrm{CP}$ that might increase the momentum of the 
convergence. However, studies by $[9,12,13]$ show that a positive effect on growth does not necessarily mean a positive effect on convergence.

There are some studies $[7,8,13,26]$ that interact the initial level of development with the $\mathrm{CP}$ variable, allowing for a coefficient of the conditional beta-convergence, i.e., $\beta$, to vary depending on the intensity of the cohesion payments or the Objective 1 treatment. Nevertheless, research uses this specification to model how the level of development (and conditions that are related to it) affects the growth outcomes of the intensity of the $\mathrm{CP}$ payments or the Objective 1 treatment. We want to present here a different approach, i.e., to interpret this interaction as a way to examine the effect of the $\mathrm{CP}$ on the conditional correlation between the initial level of development and growth, i.e., the mediating effect of the $\mathrm{CP}$ on convergence.

Since we assume (hypothesise) that the $\mathrm{CP}$ and the institutional quality not only affect growth but also that (i) the growth effect of the $\mathrm{CP}$ is mediated by the institutional quality and (ii) conditional beta-convergence, i.e., $\beta$ depends on the $\mathrm{CP}$, the institutional quality and their interaction, our approach here suggests coefficients in a model with a higher order compared with the previously most-used multiplicative terms:

$$
\begin{aligned}
g r_{i, t}=\alpha+\beta & \cdot \ln \left(Y_{i, t-1}\right)+\gamma \cdot S_{i, t}+\delta \cdot Q_{i, t}+b_{1} \cdot \ln \left(Y_{i, t-1}\right) \cdot S_{i, t}+b_{2} \cdot S_{i, t} \cdot Q_{i, t}+b_{3} \\
& \cdot \ln \left(Y_{i, t-1}\right) \cdot Q_{i, t}+b_{4} \cdot \ln \left(Y_{i, t-1}\right) \cdot S_{i, t} \cdot Q_{i, t}+c_{j} \cdot C_{j, i, t}+\mu_{i}+\varphi_{t}+\varepsilon_{i, t},
\end{aligned}
$$

where $S_{i, t}$ is a variable that proxy $\mathrm{CP}, Q_{i, t}$ is a proxy for the institutional quality, $S_{i, t} \cdot Q_{i, t}$, i.e., the interaction term between the two, represents the mediating effect of the institutional quality on growth outcomes of the CP. Multiplicative terms $\ln \left(Y_{i, t-1}\right) \cdot S_{i, t}, \ln \left(Y_{i, t-1}\right) \cdot Q_{i, t}$, and $\ln \left(Y_{i, t-1}\right) \cdot S_{i, t} \cdot Q_{i, t}$ represent the mediating effects of the $C P$, the institutional quality, and the interaction between the two on the conditional beta-convergence, respectively. To our best knowledge, just Becker et al. [17] used a 3-way multiplicative term to estimate the mediating effects of human capital and the quality of government on the outcomes of the Objective 1 payments. Our approach differs from [17] in the sense that we aim to examine how the $\mathrm{CP}$ and the institutional quality mediate regional converge.

The conditional relationships between (i) growth rate and the CP for any given values of $Q_{i, t}$, and (ii) growth rate and $\ln \left(Y_{i, t-1}\right)$, i.e., the conditional beta-convergence, for any given combination of values for $S_{i, t}$ and $Q_{i, t}$ can be estimated by

$$
\begin{gathered}
g r_{i, t}=\alpha+\delta \cdot Q_{i, t}+\left[\gamma+b_{2} \cdot Q_{i, t}\right] \cdot S_{i, t}+\left[\beta+b_{1} \cdot S_{i, t}+b_{3} \cdot Q_{i, t}+b_{4} \cdot S_{i, t} \cdot Q_{i, t}\right] \\
\cdot \ln \left(Y_{i, t-1}\right)+c_{j} \cdot C_{j, i, t}+\mu_{i}+\varphi_{t}+\varepsilon_{i, t}
\end{gathered}
$$

where expression in the first set of brackets represents the conditional marginal effect of $S_{i, t}$ on $g r_{i, t}$, i.e., the growth outcomes of the $\mathrm{CP}$ for any particular value for $Q_{t}$. A similar approach was used by [18] while estimating the effect of the quality of the government on the returns of the $\mathrm{CP}$ investment. The expression in the second set of brackets represents the conditional marginal effect of $\ln \left(Y_{i, t-1}\right)$ on $g r_{i, t}$, i.e., the conditional beta-convergence for any particular combination of values for $S_{i, t}$ and $Q_{i, t}$. We want to emphasise here that multiplicative terms in our model specification assume that the mediating effect is constant over the distribution of the mediating factor (linear interaction effect) and that the conditional effect can be at some point misleading if there is a lack of a uniform distribution of values for the mediating factors (extrapolation bias).

Following [59-61], we can argue that not only the slope of $g r_{i, t}$ on $S_{i, t}$ varies according to the value of $Q_{i, t}$, as Equation (3) shows, but also the standard error of the slope coefficient varies according to the value of $Q_{i, t}$. Reference [27] showed that the standard error of the estimated sum $\left[\hat{\gamma}+\hat{b}_{2} \cdot Q_{i, t}\right]$ is

$$
\hat{\sigma}_{\frac{\partial\left[g_{i}, t\right]}{\partial\left[S_{i, t}\right]}}=\left[\operatorname{var}(\hat{\gamma})+Q_{i, t}^{2} \cdot \operatorname{var}\left(\hat{b}_{2}\right)+2 \cdot Q_{i, t} \cdot \operatorname{cov}\left(\hat{\gamma}, \hat{b}_{2}\right)\right]^{\frac{1}{2}},
$$


which was also used by $[7,18]$. In line with the usual logic, the $t$ value for the growth outcome of the $\mathrm{CP}$, which is mediated by the institutional quality, can be calculated as

$$
t=\hat{\gamma}+\hat{b}_{2} \cdot Q_{i, t} / \hat{\sigma}_{\frac{\partial\left[r_{i, t}\right]}{\left.\partial S_{i, t}\right]}} \cdot
$$

Similarly, we can argue that the standard error of the estimated slope $\left[\hat{\beta}+\hat{b}_{1} \cdot S_{i, t}+\hat{b}_{3} \cdot Q_{i, t}+\hat{b}_{4} \cdot S_{i, t} \cdot Q_{i, t}\right]$ coefficient varies according to the values of $S_{i, t}, Q_{i, t}$ and their interaction, i.e., $S_{i, t} \cdot Q_{i, t}$. In Appendix B, we prove that the standard error of the estimated slope coefficient, i.e., the coefficient of conditional beta-convergence, is

$$
\begin{aligned}
& \hat{\sigma}_{\frac{\partial\left[g_{i, t}\right]}{\partial\left[n\left(Y_{i, t-1}\right)\right]}}=\left[\operatorname{var}(\hat{\beta})+S_{i, t}^{2} \cdot \operatorname{var}\left(\hat{b}_{1}\right)+Q_{i, t}^{2} \cdot \operatorname{var}\left(\hat{b}_{3}\right)+S_{i, t}^{2} \cdot Q_{i, t}^{2} \cdot \operatorname{var}\left(\hat{b}_{4}\right)+2 \cdot S_{i, t}\right. \\
& \cdot \operatorname{cov}\left(\hat{\beta}, \hat{b}_{1}\right)+2 \cdot Q_{i, t} \cdot \operatorname{cov}\left(\hat{\beta}, \hat{b}_{3}\right)+2 \cdot S_{i, t} \cdot Q_{i, t} \cdot \operatorname{cov}\left(\hat{\beta}, \hat{b}_{4}\right)+2 \\
& \cdot S_{i, t} \cdot Q_{i, t} \cdot \operatorname{cov}\left(\hat{b}_{1}, \hat{b}_{3}\right)+2 \cdot S_{i, t}^{2} \cdot Q_{i, t} \cdot \operatorname{cov}\left(\hat{b}_{1}, \hat{b}_{4}\right)+2 \cdot S_{i, t} \cdot Q_{i, t}^{2} \\
& \left.\cdot \operatorname{cov}\left(\hat{b}_{3}, \hat{b}_{4}\right)\right]^{\frac{1}{2}}
\end{aligned}
$$

Similarly to Equation (5), the $t$ value for the conditional beta-convergence that is mediated by the $\mathrm{CP}$, the institutional quality, and their interaction can be calculated as

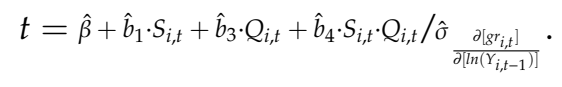

Since the estimated slopes $\left[\hat{\gamma}+\hat{b}_{2} \cdot Q_{i, t}\right]$ and $\left[\hat{\beta}+\hat{b}_{1} \cdot S_{i, t}+\hat{b}_{3} \cdot Q_{i, t}+\hat{b}_{4} \cdot S_{i, t} \cdot Q_{i, t}\right]$ as well as the standard errors associated with the slopes are not constant and, as Equations (4) and (6) show, non-linearly related to $Q_{i, t}$ and to $S_{i, t}, Q_{i, t}$, and $S_{i, t} \cdot Q_{i, t}$, respectively, the implication is that (i) there could be levels of the institution quality over which the estimated growth effect of the $\mathrm{CP}$ is positive and the levels over which this effect is negative; (ii) there could be levels of institution quality over which the estimated growth effect of the $\mathrm{CP}$ is statistically significant and the levels over which this effect is statistically insignificant; (iii) there could be a combination of the $\mathrm{CP}$ and the institutional quality that stipulates conditional beta-convergence and a combination that stipulates conditional beta-divergence; and (iv) there could be a combination of the $\mathrm{CP}$ and the institutional quality that leads to the statistically significant/insignificant conditional beta-convergence/divergence.

Despite our research design not considering an identification strategy, following [14], we argue that the $\mathrm{CP}$ variable used in our research, i.e., $S_{i, t}$, is strictly pre-determined and thus exogenous in a Granger sense, since we proxy the $\mathrm{CP}$ by funding commitments that were decided a priori and well before actual economic growth is observable [39]. While this approach helps with the issue of endogeneity, at the same time, it might, at some point, introduce a mismeasurement since, as it is well-known, planned allocations on a yearly basis and actual year-on-year expenditures can be disparate. Selection bias (i.e., the fact that regions with higher future growth potential receive more $\mathrm{CP}$ investments) is additionally minimised by applying a fixed-effects estimator and by including the initial level of development. The confoundedness issue is also addressed by including in the specification regionally identifiable capital expenditures. Moreover, following [8,62], to better capture initial conditions and to avoid reverse causality, all the righthand-side variables of Equation (2) are lagged twice, considering this to be more reasonable than the standard one-year-lagged variables. This strategy also helps at some point to capture the lagged effects of the $\mathrm{CP}$ and to take into consideration the fact that some allocations could be spent after the end of the programming period, as discussed previously.

Our empirical examining of the conditional growth and convergence outcomes of the $\mathrm{CP}$ is at the NUTS 2 and 3 disaggregation level and covers the last two fully expired programming periods, i.e., 2000-2006 and 2007-2013. Estimations include regions of the EU 25 (countries that joined the EU after 2006, i.e., Romania, Bulgaria, and Croatia are not included) for the first and EU 28 for the second programming period under consideration. A number of regions vary for different estimations due to 
the data availability, but this variation is small, and we believe its effect on the comparison of results is negligible.

As the dependent variable, we used annual growth of per capita GDP and GVA per person employed at the NUTS 2 and 3 disaggregation level as a proxies for economic growth and productivity growth at the regional level, ascertaining all shortcomings of this approach discussed in Butkus et al. [63], among many others. For the detailed explanation of the dependent variable and data source for $Y_{i, t}$, see Appendix C.1.

To proxy CP, we used the European Regional Development Fund (ERDF) and Cohesion Fund (CF) commitments combined, i.e., $\mathrm{CP}$ commitments to GDP ratio. For the detailed explanation of the variable $S_{i, t}$ and the data source, see Appendix C.2.

To proxy institutional quality at the regional level, we used the European Quality of Government Index (EQI), which focuses on perceptions as well as experiences with public sector corruption, along with the extent to which citizens believe various public sector services are impartially allocated and of good quality. For the detailed explanation of the variable $Q_{i, t}$ and the data source see Appendix C.3.

As the control variables in the economic growth model, we used

- Average annual population growth (POP).

- Investment to GDP ratio (IGDP).

- To proxy human capital—primary (PEDUC) and tertiary education (TEDUC).

- The share of workers employed in high-technology sectors (HTEC) as a proxy for innovations.

- To proxy infrastructure, we used the length of the motorways (MINFR) and length of the total railway lines (RINFR) per thousand square kilometres.

- As a proxy for agglomeration effects we used population density (PDENS).

- As a proxy for demographic structure we used the share of the working-age population (PSTR).

- To proxy the structure of the economy, we used the share of value added in the agriculture (AGVA) and service (SGVA) sectors.

- $\quad$ Proxy for a spatial interdependence (SI).

As the control variables in the productivity growth model we used

- Investment per worker (IWRK).

- To proxy human capital—primary (PEDUC) and tertiary education (TEDUC).

- For innovations (INOV) we used the number of patents per million inhabitants.

- To proxy infrastructure, we used the length of the motorways (MINFR) and length of the total railway lines (RINFR) per thousand square kilometres.

- As a proxy for agglomeration effects we used employment density (EDENS);

- To proxy the structure of the economy, we used the share of those employed in the agriculture (AEMPL) and service (SEMPL) sectors.

- $\quad$ Proxy for a spatial interdependence (SI).

Detailed information about the control variables is presented in Appendix C.4.

\section{Results and Discussion}

Table 2 presents estimates of Equation (2) for the 2000-2006 and 2007-2013 programming periods at the NUTS 2 and 3 disaggregation levels, considering two dependent variables-economic and productivity growth. The set of variables used to control other growth factors in the estimates differs due to data availability at the NUTS 2 and 3 disaggregation levels and considering the two dependent variables.

The estimated coefficients for the control variables are sensible in light of the economic theory and correspond to previous contributions. Investment is positively and significantly related to the economic and productivity growth. The share of population with primary education negatively 
and the share of the population with tertiary education positively correlate with growth, the latter being statistically insignificant. The insignificant effect of tertiary education could be caused by the fact that it takes time for an impact of the investment in human capital to manifest. The size of the high-technology sector and innovation activity have a positive effect on growth. The same is true for infrastructure. The agglomeration effect on economic and productivity growth is estimated as positive and insignificant. Since agglomeration has a twofold impact on growth, one related to a more intense interaction between economic agents, which speeds up the transfer of knowledge/ideas and reduction of transportation costs due to proximity being positive; another related to higher production costs in urban areas due to the higher price level being negative-they could offset each other. Effects of the share of the working-age population and population growth are also estimated as statistically insignificant. Both variables are remnants of the neoclassical growth model and it seems that the increase in population or working-age population does not boost the current knowledge-based economy. The predicted net growth rates (based on the intercept) appear to be positive over the 2000-2006 programming period at a level between $1.3 \%$ and $2.1 \%$ per annum, and in the crisis period (over the 2007-2013 programming period) appear to be negative at a level between $-1.7 \%$ and $-0.08 \%$ per annum. Estimated coefficients for the NUTS 2 disaggregation level are typically larger, which can be attributed to the effect of spatial heterogeneity and potential aggregation bias.

Since a lack of data, especially at the NUTS 3 disaggregation level, hinders us from modelling economic and productivity growth (using classic inputs) by using the share of value added created and the labour force employed in the agricultural and service sectors, we assume that sectoral distribution is strongly related to the availability of inputs and the changes in industry mix are not possible without the alteration of the inputs. Our estimates show that the size of the agriculture sector has a significant negative effect on growth, while the size of the service sector is positively and statistically significantly related to growth.

The literature over at least twenty years has highlighted the presence of spatial dependence in regional economic growth. Since the trade, migration, and other types of relations cause interdependence between economic performances of neighbouring territories, following thereference [26], we used the ratio of regional to national GDP as a proxy for the spatial interdependencies within countries. The estimated coefficient on this ratio is positive, evidencing that spatial interdependence is positively related to growth, but the estimated effect is not significant at a standard confidence level. Since this variable also shows the size (importance) of a particular region in the context of a national economy, a positive correlation with the development level could at some point inflate standard errors and yield insignificance. Although this ratio allows to proxy only interactions between regions within the same country, the Pesaran CD test shows the absence of the spatial dependence. 
Table 2. Fixed effect estimates of Equation (2).

\begin{tabular}{|c|c|c|c|c|c|c|c|c|c|}
\hline \multirow{4}{*}{ Variable } & \multirow{4}{*}{ Parameter } & \multicolumn{4}{|c|}{ 2000-2006 Programming Period } & \multicolumn{4}{|c|}{ 2007-2013 Programming Period } \\
\hline & & \multicolumn{2}{|c|}{ NUTS 3} & \multicolumn{2}{|c|}{ NUTS 2} & \multicolumn{2}{|c|}{ NUTS 3} & \multicolumn{2}{|c|}{ NUTS 2} \\
\hline & & $\begin{array}{l}\text { Dependent } \\
\text { Variable- } \\
\text { Economic } \\
\text { Growth }\end{array}$ & $\begin{array}{c}\text { Dependent } \\
\text { Variable- } \\
\text { Productivity } \\
\text { Growth }\end{array}$ & $\begin{array}{l}\text { Dependent } \\
\text { Variable- } \\
\text { Economic } \\
\text { Growth }\end{array}$ & $\begin{array}{c}\text { Dependent } \\
\text { Variable- } \\
\text { Productivity } \\
\text { Growth }\end{array}$ & $\begin{array}{l}\text { Dependent } \\
\text { Variable- } \\
\text { Economic } \\
\text { Growth }\end{array}$ & $\begin{array}{c}\text { Dependent } \\
\text { Variable- } \\
\text { Productivity } \\
\text { Growth }\end{array}$ & $\begin{array}{l}\text { Dependent } \\
\text { Variable- } \\
\text { Economic } \\
\text { Growth }\end{array}$ & $\begin{array}{c}\text { Dependent } \\
\text { Variable- } \\
\text { Productivity } \\
\text { Growth }\end{array}$ \\
\hline & & (I) & (II) & (III) & (IV) & (V) & (VI) & (VII) & (VIII) \\
\hline Intercept & $\alpha$ & $\begin{array}{c}0.0207^{* * *} \\
(0.0013)\end{array}$ & $\begin{array}{c}0.0128^{* * *} \\
(0.0010)\end{array}$ & $\begin{array}{c}0.0150^{* * *} \\
(0.0030)\end{array}$ & $\begin{array}{c}0.0133 * * * \\
(0.0026)\end{array}$ & $\begin{array}{c}-0.0170 * * * \\
(0.0010)\end{array}$ & $\begin{array}{c}-0.0158^{* * *} \\
(0.0010)\end{array}$ & $\begin{array}{c}-0.0128 * * * \\
(0.0030)\end{array}$ & $\begin{array}{c}-0.0080^{* * * *} \\
(0.0030)\end{array}$ \\
\hline $\ln (Y)$ & $\beta$ & $\begin{array}{c}-0.0114^{* * *} \\
(0.0010)\end{array}$ & $\begin{array}{c}-0.0183^{* * *} \\
(0.0012)\end{array}$ & $\begin{array}{c}-0.0116^{* * *} \\
(0.0026)\end{array}$ & $\begin{array}{c}-0.0129^{* * *} \\
(0.0028)\end{array}$ & $\begin{array}{c}-0.0165^{* * *} \\
(0.0012)\end{array}$ & $\begin{array}{c}-0.0159 * * * \\
(0.0014)\end{array}$ & $\begin{array}{c}-0.0134^{* * *} \\
(0.0029)\end{array}$ & $\begin{array}{c}-0.0175^{* * *} \\
(0.0064)\end{array}$ \\
\hline$S$ & $\gamma$ & $\begin{array}{l}-0.0233 \\
(0.0184)\end{array}$ & $\begin{array}{c}-0.0319 * \\
(0.0187)\end{array}$ & $\begin{array}{c}-0.0228 \text { * } \\
(0.0124)\end{array}$ & $\begin{array}{l}-0.0059 \\
(0.0450)\end{array}$ & $\begin{array}{c}0.0656^{* * *} \\
(0.0123)\end{array}$ & $\begin{array}{c}0.0671^{* * * *} \\
(0.0125)\end{array}$ & $\begin{array}{c}0.1522 * * * \\
(0.0286)\end{array}$ & $\begin{array}{c}0.1096^{* * *} \\
(0.0285)\end{array}$ \\
\hline$Q$ & $\delta$ & $\begin{array}{c}0.0773^{* * * *} \\
(0.0126)\end{array}$ & $\begin{array}{c}0.0717^{* * *} \\
(0.0165)\end{array}$ & $\begin{array}{l}0.0368 * \\
(0.0208)\end{array}$ & $\begin{array}{l}0.0775 * \\
(0.0395)\end{array}$ & $\begin{array}{c}0.0502^{* * *} \\
(0.0096)\end{array}$ & $\begin{array}{c}0.0135^{* *} \\
(0.0068)\end{array}$ & $\begin{array}{c}0.0870^{* * * *} \\
(0.0223)\end{array}$ & $\begin{array}{c}0.0664^{* * *} \\
(0.0227)\end{array}$ \\
\hline $\ln (Y) S$ & $b_{1}$ & $\begin{array}{c}0.0026 \\
(0.0019)\end{array}$ & $\begin{array}{c}0.0029 \\
(0.0018)\end{array}$ & $\begin{array}{l}0.0129 * \\
(0.0067)\end{array}$ & $\begin{array}{c}0.0004 \\
(0.0048)\end{array}$ & $\begin{array}{c}-0.0071^{* * *} \\
(0.0013)\end{array}$ & $\begin{array}{c}-0.0065^{* * *} \\
(0.0012)\end{array}$ & $\begin{array}{c}-0.0162 * * * \\
(0.0031)\end{array}$ & $\begin{array}{c}-0.0203 * * * \\
(0.0056)\end{array}$ \\
\hline$S Q$ & $b_{2}$ & $\begin{array}{c}0.0656^{* * *} \\
(0.0217)\end{array}$ & $\begin{array}{c}0.0554^{* *} \\
(0.0230)\end{array}$ & $\begin{array}{c}0.1459 * * * \\
(0.0493)\end{array}$ & $\begin{array}{c}0.1051 \\
(0.0831)\end{array}$ & $\begin{array}{c}0.0254^{* * * *} \\
(0.0092)\end{array}$ & $\begin{array}{c}0.0240 * * * \\
(0.0092)\end{array}$ & $\begin{array}{c}0.0555 * * \\
(0.0250)\end{array}$ & $\begin{array}{l}0.0207 * * \\
(0.0105)\end{array}$ \\
\hline $\ln (Y) Q$ & $b_{3}$ & $\begin{array}{c}0.0079 * * * \\
(0.0013)\end{array}$ & $\begin{array}{c}0.0072 * * * \\
(0.0015)\end{array}$ & $\begin{array}{c}0.0038 \\
(0.0031)\end{array}$ & $\begin{array}{c}0.0076^{* *} \\
(0.0037)\end{array}$ & $\begin{array}{c}0.0063^{* * *} \\
(0.0010)\end{array}$ & $\begin{array}{c}0.0016 \\
(0.0010)\end{array}$ & $\begin{array}{c}0.0093^{* * * *} \\
(0.0022)\end{array}$ & $\begin{array}{c}0.0102 * * * \\
(0.0034)\end{array}$ \\
\hline $\ln (Y) S Q$ & $b_{4}$ & $\begin{array}{c}0.0070 * * * \\
(0.0023)\end{array}$ & $\begin{array}{c}0.0051^{* *} \\
(0.0022)\end{array}$ & $\begin{array}{c}0.0256^{* * *} \\
(0.0073)\end{array}$ & $\begin{array}{c}0.0098 \\
(0.0060)\end{array}$ & $\begin{array}{c}-0.0024^{* *} \\
(0.0010)\end{array}$ & $\begin{array}{c}-0.0020 \text { ** } \\
(0.0010)\end{array}$ & $\begin{array}{c}-0.0049 \text { * } \\
(0.0026)\end{array}$ & $\begin{array}{l}-0.0052 \\
(0.0101)\end{array}$ \\
\hline$\Delta \ln (P O P)$ & $c_{P O P}$ & $\begin{array}{l}-0.0136 \\
(0.0195)\end{array}$ & & $\begin{array}{l}-0.0073 \\
(0.0089)\end{array}$ & & $\begin{array}{l}-0.0155 \\
(0.0101)\end{array}$ & & $\begin{array}{l}-0.0054 \\
(0.0039)\end{array}$ & \\
\hline$I G D P$ & $c_{I G D P}$ & & & $\begin{array}{c}0.0012^{* * *} \\
(0.0004)\end{array}$ & & & & $\begin{array}{c}0.0014^{* * * *} \\
(0.0004)\end{array}$ & \\
\hline
\end{tabular}


Table 2. Cont.

\begin{tabular}{|c|c|c|c|c|c|c|c|c|c|}
\hline \multirow{4}{*}{ Variable } & \multirow{4}{*}{ Parameter } & \multicolumn{4}{|c|}{ 2000-2006 Programming Period } & \multicolumn{4}{|c|}{ 2007-2013 Programming Period } \\
\hline & & \multicolumn{2}{|c|}{ NUTS 3} & \multicolumn{2}{|c|}{ NUTS 2} & \multicolumn{2}{|c|}{ NUTS 3} & \multicolumn{2}{|c|}{ NUTS 2} \\
\hline & & $\begin{array}{c}\text { Dependent } \\
\text { Variable- } \\
\text { Economic } \\
\text { Growth }\end{array}$ & $\begin{array}{c}\text { Dependent } \\
\text { Variable- } \\
\text { Productivity } \\
\text { Growth }\end{array}$ & $\begin{array}{c}\text { Dependent } \\
\text { Variable- } \\
\text { Economic } \\
\text { Growth }\end{array}$ & $\begin{array}{c}\text { Dependent } \\
\text { Variable- } \\
\text { Productivity } \\
\text { Growth }\end{array}$ & $\begin{array}{l}\text { Dependent } \\
\text { Variable- } \\
\text { Economic } \\
\text { Growth }\end{array}$ & $\begin{array}{c}\text { Dependent } \\
\text { Variable- } \\
\text { Productivity } \\
\text { Growth }\end{array}$ & $\begin{array}{l}\text { Dependent } \\
\text { Variable- } \\
\text { Economic } \\
\text { Growth }\end{array}$ & $\begin{array}{c}\text { Dependent } \\
\text { Variable- } \\
\text { Productivity } \\
\text { Growth }\end{array}$ \\
\hline & & (I) & (II) & (III) & (IV) & (V) & (VI) & (VII) & (VIII) \\
\hline $\ln (I W R K)$ & $c_{I W R K}$ & & & & $\begin{array}{c}0.0174^{* * *} \\
(0.0015)\end{array}$ & & & & $\begin{array}{c}0.0190^{* * *} \\
(0.0013)\end{array}$ \\
\hline PEDU & $c_{P E D U C}$ & & & $\begin{array}{c}-0.0868^{* *} \\
(0.0376)\end{array}$ & $\begin{array}{c}-0.0619 * * \\
(0.0286)\end{array}$ & & & $\begin{array}{c}-0.0687 \text { * } \\
(0.0426)\end{array}$ & $\begin{array}{c}-0.0696^{* *} \\
(0.0347)\end{array}$ \\
\hline TEDUC & $c_{T E D U C}$ & & & $\begin{array}{c}0.0123 \\
(0.0533)\end{array}$ & $\begin{array}{c}0.0201 \\
(0.0491)\end{array}$ & & & $\begin{array}{l}0.0171 * \\
(0.0104)\end{array}$ & $\begin{array}{c}0.0136 * * \\
(0.0069)\end{array}$ \\
\hline HTEC & $c_{H T E C}$ & & & $\begin{array}{l}0.0030 * \\
(0.0017)\end{array}$ & & & & $\begin{array}{c}0.0027^{* *} \\
(0.0013)\end{array}$ & \\
\hline $\ln (I N O V)$ & $c_{I N O V}$ & & $\begin{array}{c}0.2224 \\
(0.6118)\end{array}$ & & $\begin{array}{c}0.1816 \\
(0.6056)\end{array}$ & & $\begin{array}{c}0.3612 \\
(0.6022)\end{array}$ & & $\begin{array}{c}0.3368 \\
(0.7578)\end{array}$ \\
\hline $\ln (M I N F R)$ & $c_{M I N F R}$ & & & $\begin{array}{c}0.0028^{* *} \\
(0.0011)\end{array}$ & $\begin{array}{c}0.0028^{* *} \\
(0.0011)\end{array}$ & & & $\begin{array}{l}0.0023 * \\
(0.0012)\end{array}$ & $\begin{array}{l}0.0022 * \\
(0.0013)\end{array}$ \\
\hline $\ln (R I N F R)$ & $c_{R I N F R}$ & & & $\begin{array}{c}0.0112^{* *} \\
(0.0050)\end{array}$ & $\begin{array}{c}0.0236^{* * *} \\
(0.0061)\end{array}$ & & & $\begin{array}{c}0.0122 * * * \\
(0.0038)\end{array}$ & $\begin{array}{c}0.0128^{* * *} \\
(0.0042)\end{array}$ \\
\hline $\ln ($ PDENS $)$ & $c_{P D E N S}$ & $\begin{array}{c}0.0616 \\
(0.0492)\end{array}$ & & $\begin{array}{c}0.0281 \\
(0.0845)\end{array}$ & & $\begin{array}{l}0.0780 * \\
(0.0422)\end{array}$ & & $\begin{array}{l}0.0800 * \\
(0.0454)\end{array}$ & \\
\hline $\ln (E D E N S)$ & $c_{E D E N S}$ & & $\begin{array}{c}0.0501 \\
(0.0427)\end{array}$ & & $\begin{array}{c}0.0325 \\
(0.0727)\end{array}$ & & $\begin{array}{c}0.0643 \\
(0.0428)\end{array}$ & & $\begin{array}{l}0.0649 * \\
(0.0387)\end{array}$ \\
\hline PSTR & $C_{P S T R}$ & $\begin{array}{c}0.0006 \\
(0.0008)\end{array}$ & & $\begin{array}{c}0.0014 \\
(0.0017)\end{array}$ & & $\begin{array}{c}0.0008 \\
(0.0007)\end{array}$ & & $\begin{array}{c}0.0007 \\
(0.0008)\end{array}$ & \\
\hline$A E M P L$ & $c_{A E M P L}$ & & $\begin{array}{c}-0.0013^{* * *} \\
(0.0002)\end{array}$ & & $\begin{array}{c}-0.0014^{* * *} \\
(0.0002)\end{array}$ & & $\begin{array}{c}-0.0012 * * * \\
(0.0002)\end{array}$ & & $\begin{array}{c}-0.0017^{* * *} \\
(0.0002)\end{array}$ \\
\hline
\end{tabular}


Table 2. Cont.

\begin{tabular}{|c|c|c|c|c|c|c|c|c|c|}
\hline \multirow{4}{*}{ Variable } & \multirow{4}{*}{ Parameter } & \multicolumn{4}{|c|}{ 2000-2006 Programming Period } & \multicolumn{4}{|c|}{ 2007-2013 Programming Period } \\
\hline & & \multicolumn{2}{|c|}{ NUTS 3} & \multicolumn{2}{|c|}{ NUTS 2} & \multicolumn{2}{|c|}{ NUTS 3} & \multicolumn{2}{|c|}{ NUTS 2} \\
\hline & & $\begin{array}{l}\text { Dependent } \\
\text { Variable- } \\
\text { Economic } \\
\text { Growth }\end{array}$ & $\begin{array}{c}\text { Dependent } \\
\text { Variable- } \\
\text { Productivity } \\
\text { Growth }\end{array}$ & $\begin{array}{l}\text { Dependent } \\
\text { Variable- } \\
\text { Economic } \\
\text { Growth }\end{array}$ & $\begin{array}{c}\text { Dependent } \\
\text { Variable- } \\
\text { Productivity } \\
\text { Growth }\end{array}$ & $\begin{array}{l}\text { Dependent } \\
\text { Variable- } \\
\text { Economic } \\
\text { Growth }\end{array}$ & $\begin{array}{c}\text { Dependent } \\
\text { Variable- } \\
\text { Productivity } \\
\text { Growth }\end{array}$ & $\begin{array}{l}\text { Dependent } \\
\text { Variable- } \\
\text { Economic } \\
\text { Growth }\end{array}$ & $\begin{array}{c}\text { Dependent } \\
\text { Variable- } \\
\text { Productivity } \\
\text { Growth }\end{array}$ \\
\hline & & (I) & (II) & (III) & (IV) & (V) & (VI) & (VII) & (VIII) \\
\hline SEMPL & ${ }^{S}$ SEMPL & & $\begin{array}{c}0.0013^{* * *} \\
(0.0001)\end{array}$ & & $\begin{array}{c}0.0014^{* * *} \\
(0.0001)\end{array}$ & & $\begin{array}{c}0.0015^{* * *} \\
(0.0001)\end{array}$ & & $\begin{array}{c}0.0015^{* * *} \\
(0.0001)\end{array}$ \\
\hline$A G V A$ & $c_{A G V A}$ & $\begin{array}{c}-0.0017^{* * *} \\
(0.0002)\end{array}$ & & $\begin{array}{c}-0.0013^{* * *} \\
(0.0002)\end{array}$ & & $\begin{array}{c}-0.0014^{* * *} \\
(0.0002)\end{array}$ & & $\begin{array}{c}-0.0015^{* * *} \\
(0.0002)\end{array}$ & \\
\hline$S G V A$ & $c_{S G V A}$ & $\begin{array}{c}0.0015^{* * *} \\
(0.0001)\end{array}$ & & $\begin{array}{c}0.0013^{* * * *} \\
(0.0002)\end{array}$ & & $\begin{array}{c}0.0013^{* * *} \\
(0.0001)\end{array}$ & & $\begin{array}{c}0.0014^{* * *} \\
(0.0001)\end{array}$ & \\
\hline SI & $c_{S I}$ & $\begin{array}{l}0.0716 * \\
(0.0444)\end{array}$ & $\begin{array}{l}0.0760 * \\
(0.0418)\end{array}$ & $\begin{array}{l}0.0789 * \\
(0.0444)\end{array}$ & $\begin{array}{c}0.0623 \\
(0.0430)\end{array}$ & $\begin{array}{l}0.2031 * \\
(0.1188)\end{array}$ & $\begin{array}{l}0.2154 * \\
(0.1264)\end{array}$ & $\begin{array}{c}0.1949 \\
(0.1221)\end{array}$ & $\begin{array}{l}0.1963 * \\
(0.1096)\end{array}$ \\
\hline Numb & regions & 1248 & 1247 & 257 & 256 & 1326 & 1326 & 270 & 270 \\
\hline $\mathrm{Ob}$ & ions & 5429 & 5125 & 1208 & 1160 & 6458 & 6153 & 1350 & 1326 \\
\hline Avg. o & r group & 4.35 & 4.11 & 4.70 & 4.53 & 4.87 & 4.64 & 5.00 & 4.91 \\
\hline With & quared & 0.6895 & 0.5894 & 0.6702 & 0.5003 & 0.6772 & 0.5020 & 0.6044 & 0.5321 \\
\hline Pesara & test ${ }^{(1)}$ & [0.1502] & [0.1514] & [0.1926] & [0.1475] & [0.1093] & [0.1150] & [0.0883] & [0.1258] \\
\hline & & $1.06 \times 10^{-6}$ & $1.51 \times 10^{-6}$ & $6.90 \times 10^{-6}$ & $7.85 \times 10^{-6}$ & $1.47 \times 10^{-6}$ & $1.85 \times 10^{-6}$ & $8.46 \times 10^{-6}$ & $8.47 \times 10^{-6}$ \\
\hline & & $3.39 \times 10^{-4}$ & $3.49 \times 10^{-4}$ & $4.15 \times 10^{-3}$ & $2.49 \times 10^{-3}$ & $1.51 \times 10^{-4}$ & $1.55 \times 10^{-4}$ & $8.18 \times 10^{-4}$ & $8.14 \times 10^{-4}$ \\
\hline & & $3.74 \times 10^{-6}$ & $3.17 \times 10^{-6}$ & $4.49 \times 10^{-5}$ & $2.31 \times 10^{-5}$ & $1.75 \times 10^{-6}$ & $1.53 \times 10^{-6}$ & $9.32 \times 10^{-6}$ & $9.95 \times 10^{-6}$ \\
\hline & & $4.72 \times 10^{-4}$ & $5.28 \times 10^{-4}$ & $4.94 \times 10^{-3}$ & $3.98 \times 10^{-3}$ & $8.43 \times 10^{-5}$ & $8.45 \times 10^{-5}$ & $6.25 \times 10^{-4}$ & $3.52 \times 10^{-4}$ \\
\hline & & $1.60 \times 10^{-6}$ & $2.36 \times 10^{-6}$ & $9.33 \times 10^{-6}$ & $1.34 \times 10^{-5}$ & $9.25 \times 10^{-7}$ & $1.02 \times 10^{-6}$ & $4.80 \times 10^{-6}$ & $4.39 \times 10^{-6}$ \\
\hline & & $5.12 \times 10^{-6}$ & $4.78 \times 10^{-6}$ & $5.36 \times 10^{-5}$ & $3.64 \times 10^{-5}$ & $9.90 \times 10^{-7}$ & $8.36 \times 10^{-7}$ & $6.93 \times 10^{-6}$ & $6.26 \times 10^{-6}$ \\
\hline & & $-3.03 \times 10^{-7}$ & $-6.79 \times 10^{-7}$ & $-5.42 \times 10^{-6}$ & $-4.70 \times 10^{-6}$ & $-3.58 \times 10^{-7}$ & $-4.80 \times 10^{-7}$ & $-1.58 \times 10^{-6}$ & $-1.86 \times 10^{-6}$ \\
\hline & & $9.01 \times 10^{-8}$ & $6.96 \times 10^{-7}$ & $-2.85 \times 10^{-7}$ & $1.44 \times 10^{-6}$ & $1.67 \times 10^{-7}$ & $5.65 \times 10^{-7}$ & $1.11 \times 10^{-6}$ & $1.09 \times 10^{-6}$ \\
\hline & & $2.71 \times 10^{-7}$ & $-2.06 \times 10^{-7}$ & $3.76 \times 10^{-6}$ & $3.24 \times 10^{-6}$ & $4.27 \times 10^{-8}$ & $-1.02 \times 10^{-7}$ & $1.01 \times 10^{-6}$ & $1.07 \times 10^{-7}$ \\
\hline
\end{tabular}


Table 2. Cont.

\begin{tabular}{|c|c|c|c|c|c|c|c|c|}
\hline \multirow{4}{*}{ Parameter } & \multicolumn{4}{|c|}{ 2000-2006 Programming Period } & \multicolumn{4}{|c|}{ 2007-2013 Programming Period } \\
\hline & \multicolumn{2}{|c|}{ NUTS 3} & \multicolumn{2}{|c|}{ NUTS 2} & \multicolumn{2}{|c|}{ NUTS 3} & \multicolumn{2}{|c|}{ NUTS 2} \\
\hline & $\begin{array}{l}\text { Dependent } \\
\text { Variable- } \\
\text { Economic } \\
\text { Growth }\end{array}$ & $\begin{array}{c}\text { Dependent } \\
\text { Variable- } \\
\text { Productivity } \\
\text { Growth }\end{array}$ & $\begin{array}{l}\text { Dependent } \\
\text { Variable- } \\
\text { Economic } \\
\text { Growth }\end{array}$ & $\begin{array}{c}\text { Dependent } \\
\text { Variable- } \\
\text { Productivity } \\
\text { Growth }\end{array}$ & $\begin{array}{l}\text { Dependent } \\
\text { Variable- } \\
\text { Economic } \\
\text { Growth }\end{array}$ & $\begin{array}{c}\text { Dependent } \\
\text { Variable- } \\
\text { Productivity } \\
\text { Growth }\end{array}$ & $\begin{array}{l}\text { Dependent } \\
\text { Variable- } \\
\text { Economic } \\
\text { Growth }\end{array}$ & $\begin{array}{c}\text { Dependent } \\
\text { Variable- } \\
\text { Productivity } \\
\text { Growth }\end{array}$ \\
\hline & (I) & (II) & (III) & (IV) & (V) & (VI) & (VII) & (VIII) \\
\hline $\operatorname{cov}\left(\hat{\gamma}, \hat{b}_{2}\right)$ & $3.13 \times 10^{-4}$ & $3.39 \times 10^{-4}$ & $2.86 \times 10^{-3}$ & $1.38 \times 10^{-3}$ & $8.50 \times 10^{-5}$ & $9.16 \times 10^{-5}$ & $5.02 \times 10^{-4}$ & $3.84 \times 10^{-4}$ \\
\hline $\operatorname{cov}\left(\hat{b}_{1}, \hat{b}_{3}\right)$ & $5.28 \times 10^{-8}$ & $-4.61 \times 10^{-7}$ & $6.36 \times 10^{-6}$ & $3.26 \times 10^{-6}$ & $-6.59 \times 10^{-8}$ & $-2.16 \times 10^{-7}$ & $-1.26 \times 10^{-6}$ & $-1.32 \times 10^{-6}$ \\
\hline $\operatorname{cov}\left(\hat{b}_{1}, \hat{b}_{4}\right)$ & $3.40 \times 10^{-6}$ & $3.04 \times 10^{-6}$ & $3.11 \times 10^{-5}$ & $1.29 \times 10^{-5}$ & $9.88 \times 10^{-7}$ & $9.01 \times 10^{-7}$ & $5.49 \times 10^{-6}$ & $4.59 \times 10^{-6}$ \\
\hline $\operatorname{cov}\left(\hat{b}_{3}, \hat{b}_{4}\right)$ & $-7.78 \times 10^{-7}$ & $-1.41 \times 10^{-6}$ & $-4.25 \times 10^{-6}$ & $-9.67 \times 10^{-6}$ & $-3.40 \times 10^{-7}$ & $-3.80 \times 10^{-7}$ & $-2.79 \times 10^{-6}$ & $-2.55 \times 10^{-6}$ \\
\hline
\end{tabular}


Figure 1 shows the conditional economic and productivity growth outcomes of the $\mathrm{CP}$ at the NUTS 2 and 3 disaggregation level over the 2000-2006 programming period that are mediated by institutional quality.

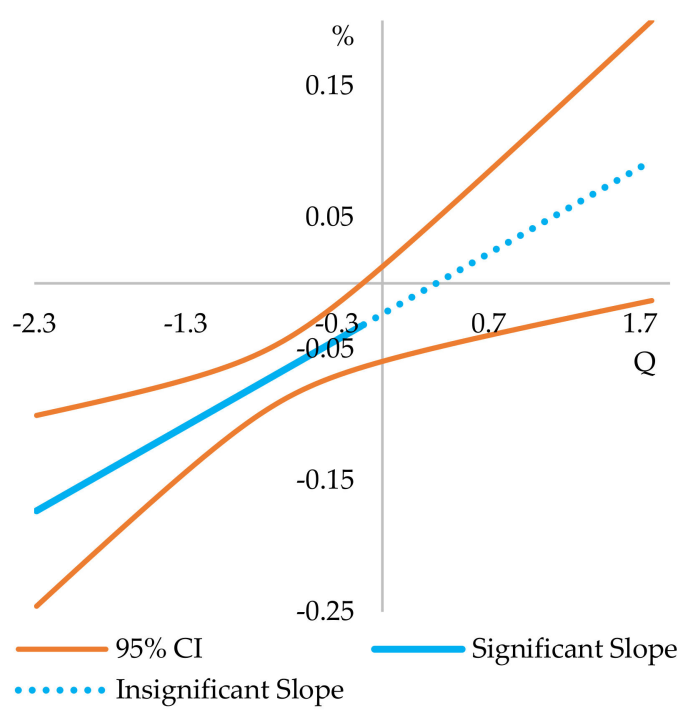

(a)

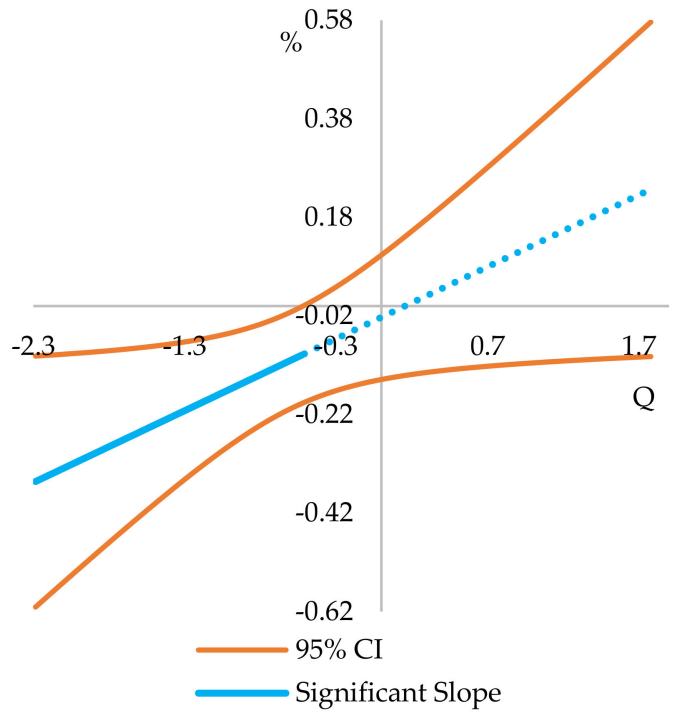

(c)

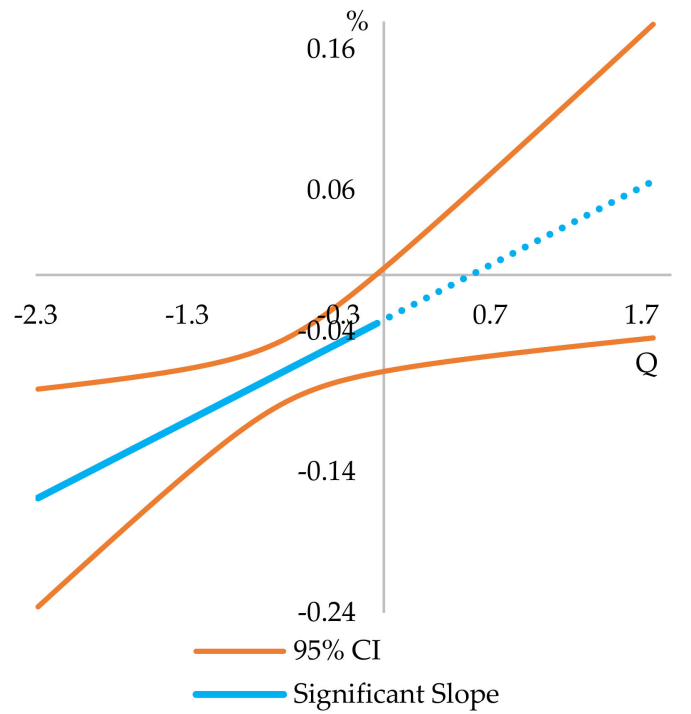

(b)

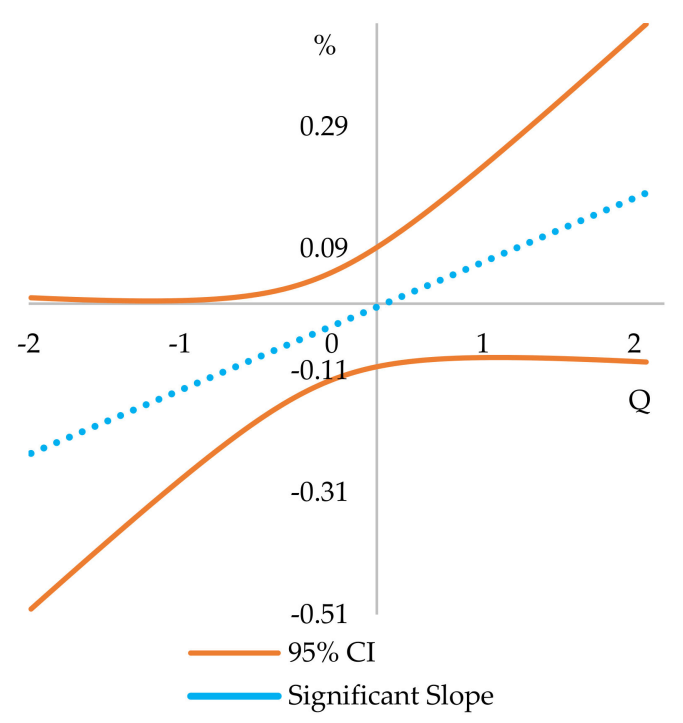

(d)

Figure 1. A range of estimated slope coefficients (slope) of $g r_{i, t}$ on $S_{i, t}$ according to the value of $Q_{i, t}$ and $95 \%$ confidence interval over the 2000-2006 programming period. A point on a slope shows an effect of $1 \%$ intensity of European Regional Development Fund (ERDF) and Cohesion Fund (CF) commitments on a growth rate for a particular value of $Q_{i, t}$. (a) Represents conditional economic growth outcomes of the CP at the NUTS 3 disaggregation level. (b) Represents conditional productivity growth outcomes of the CP at the NUTS 3 disaggregation level. (c) Represents conditional economic growth outcomes of the CP at the NUTS 2 disaggregation level. (d) Represents conditional productivity growth outcomes of the CP at the NUTS 2 disaggregation level.

The estimates show that institutional quality positively affects the growth outcomes of the $\mathrm{CP}$, i.e., the likelihood of transferring $\mathrm{CP}$ commitments to growth and productivity is higher in regions characterised as having good institutions. The estimates also suggest that a relatively bad institutional environment is related to adverse and statistically significant growth outcomes of the CP. In contrast, the relatively good institutional environment is linked to positive but insignificant growth outcomes. 
Comparing the estimated ranges of the $Q_{i, t}$ values, which condition different growth outcomes of the CP (see Table 3) with the distribution of the estimated $Q_{i, t}$ values over the 2000-2006 programming period (see Figure A1 in Appendix C.3.), we can conclude that (i) negative and significant growth outcomes of the $\mathrm{CP}$ were in all regions of Latvia, Lithuania, Poland, and Slovakia, in the majority regions of Italy and Greece-except for a few with untypically high (for a given country) $Q_{i, t}$ values—and in half of the regions of the Czech Republic and a few regions of Hungary with extremely low (for a given country) $Q_{i, t}$ values; (ii) positive but statistically insignificant growth outcomes of the CP were in all regions of Denmark, Ireland, the Netherlands, Austria, Finland, and Sweden, in the majority regions of Germany and the United Kingdom, as well as in a few regions of Belgium and France. Other countries/regions showed very mixed results depending on the outcome variable and disaggregation level under consideration.

Table 3. Ranges of $Q_{i, t}$ values that condition the different signs and significance of the estimated slope coefficient of $g r_{i, t}$ on $S_{i, t}$.

\begin{tabular}{|c|c|c|c|c|c|c|}
\hline $\begin{array}{c}\text { Programming } \\
\text { Period }\end{array}$ & $\begin{array}{l}\text { Outcome } \\
\text { Variable }\end{array}$ & $\begin{array}{c}\text { Disaggregation } \\
\text { Level }\end{array}$ & $\begin{array}{l}\text { Range of } Q_{i, t} \\
\text { Values That } \\
\text { Condition } \\
\text { Negative and } \\
\text { Significant } \\
\text { Outcomes of } \\
\text { Cohesion } \\
\text { Policy }\end{array}$ & $\begin{array}{l}\text { Range of } Q_{i, t} \\
\text { Values That } \\
\text { Condition } \\
\text { Negative and } \\
\text { Insignificant } \\
\text { Outcomes of } \\
\text { Cohesion } \\
\text { Policy }\end{array}$ & $\begin{array}{c}\text { Range of } \\
Q_{i, t} \text { Values } \\
\text { That } \\
\text { Condition } \\
\text { Positive and } \\
\text { Insignificant } \\
\text { Outcomes } \\
\text { of Cohesion } \\
\text { Policy }\end{array}$ & $\begin{array}{c}\text { Range of } \\
Q_{i, t} \text { Values } \\
\text { That } \\
\text { Condition } \\
\text { Positive and } \\
\text { Significant } \\
\text { Outcomes } \\
\text { of Cohesion } \\
\text { Policy }\end{array}$ \\
\hline \multirow{4}{*}{ 2000-2006 } & Economic & NUTS 2 & $<-0.52$ & $-0.52-0.16$ & $>0.16$ & - \\
\hline & growth & NUTS 3 & $<-0.14$ & $-0.14-0.36$ & $>0.36$ & - \\
\hline & Productivity & NUTS 2 & - & $<-0.05$ & $>-0.05$ & - \\
\hline & growth & NUTS 3 & $<-0.06$ & $-0.06-0.56$ & $>0.56$ & - \\
\hline \multirow{4}{*}{ 2007-2013 } & Economic & NUTS 2 & - & $<-2.75$ & $-2.75--1.70$ & $>-1.70$ \\
\hline & growth & NUTS 3 & - & $<-2.60$ & $-2.60--1.76$ & $>-1.76$ \\
\hline & Productivity & NUTS 2 & - & - & $>-2.37$ & $>-2.37$ \\
\hline & growth & NUTS 3 & - & $<-2.80$ & $-2.80--1.94$ & $>-1.94$ \\
\hline
\end{tabular}

Our findings are in line with [37] who revealed a positive but insignificant impact of the CP on productivity in EU-10 NUTS 1 regions and concluded that Southern EU countries (France, Greece, Italy, Portugal, and Spain) are less efficient in the management of the $\mathrm{CP}$ funds in comparison with Northern countries (Austria, Ireland, Finland, Germany, and the UK), although they received more cohesion investment. Our research results are also in line with [64] who revealed a positive but insignificant effect on growth in 70 NUTS 1 and 2 regions of Germany, Italy, and Spain, as well as with Becker et al. [17], since the authors concluded that almost all new EU MSs are not able to turn CP commitments into growth due to the insufficient level of institutional quality. Our results also support views of $[5,6,41]$, who found that the significant adverse effect on growth and productivity depends on political behaviour and intervention, an area that could also be determined by political behaviour.

Figure 2 shows the conditional economic and productivity growth outcomes of the $\mathrm{CP}$ at the NUTS 2 and 3 disaggregation level over the 2007-2013 programming period that are mediated by institutional quality. As over the previous programming period, estimates show that institutional quality is positively related to the growth outcomes of the $\mathrm{CP}$, i.e., better institutions in regions that receive $\mathrm{CP}$ support increase the likelihood to transfer investment into growth and productivity. The estimates suggest that relatively bad institutional environment is related to statistically insignificant outcomes of the $\mathrm{CP}$, whereas the relatively good institutional environment is related to positive and statistically significant outcomes. 


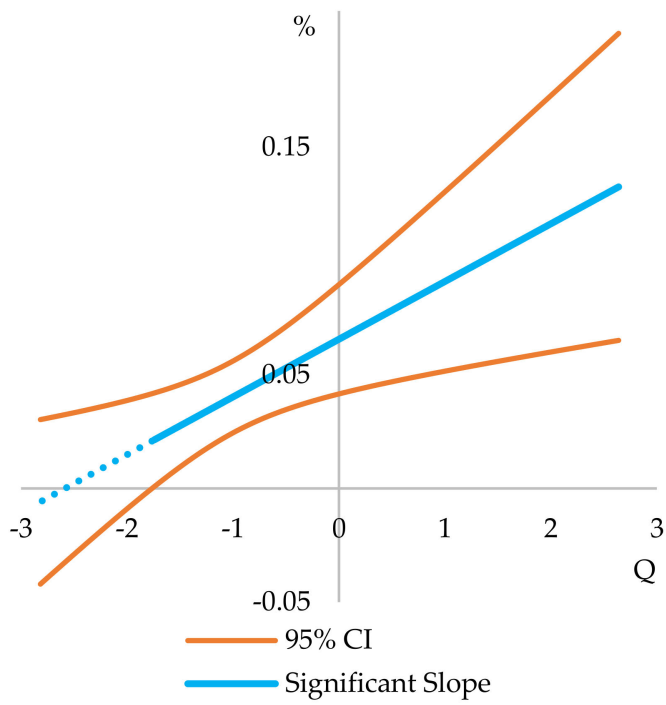

(a)

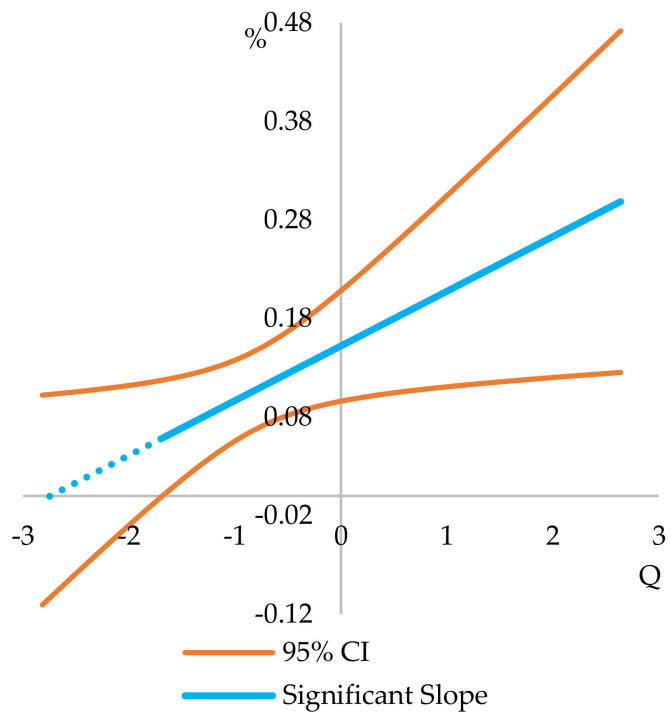

(c)

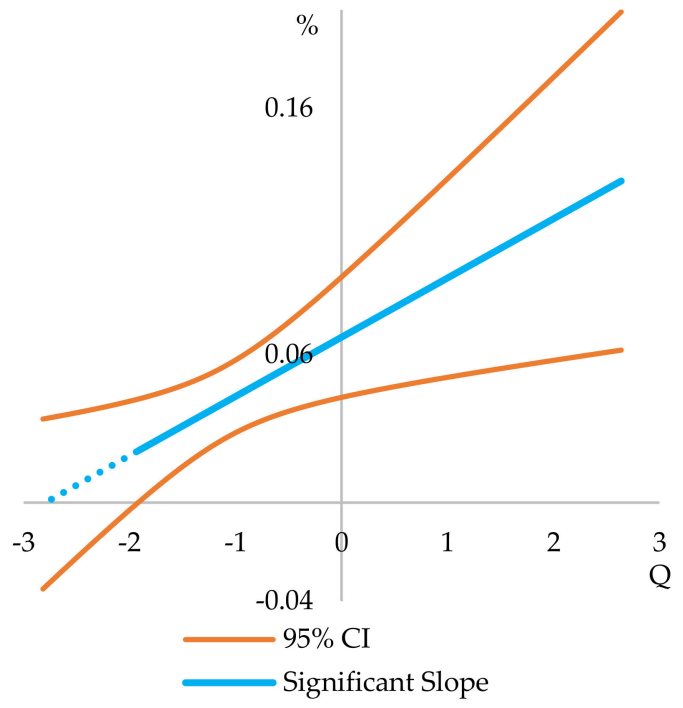

(b)

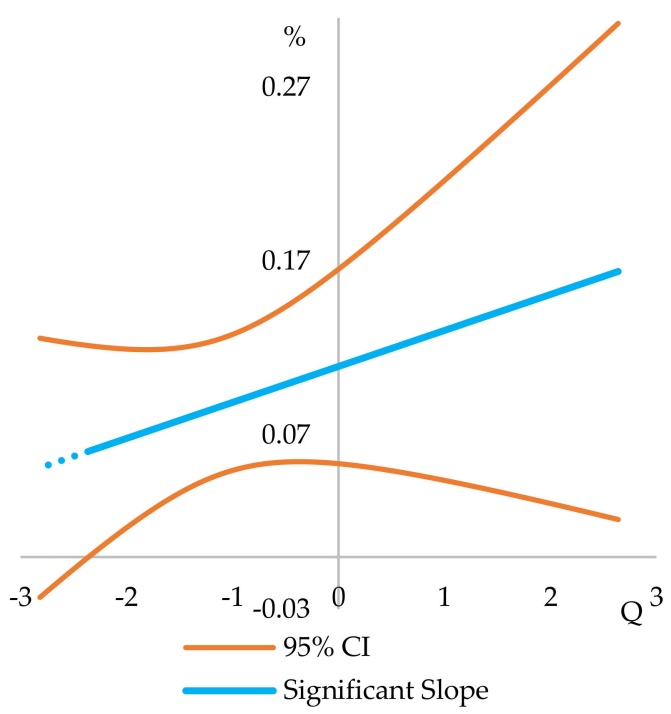

(d)

Figure 2. A range of estimated slope coefficients (slope) of $g r_{i, t}$ on $S_{i, t}$ according to the value of $Q_{i, t}$ and $95 \%$ confidence interval over the 2007-2013 programming period. A point on a slope shows an effect of $1 \%$ intensity of ERDF and CF commitments on a growth rate for a particular value of $Q_{i, t}$.

(a) Represents conditional economic growth outcomes of the CP at the NUTS 3 disaggregation level.

(b) Represents conditional productivity growth outcomes of the CP at the NUTS 3 disaggregation level.

(c) Represents conditional economic growth outcomes of the CP at the NUTS 2 disaggregation level.

(d) Represents conditional productivity growth outcomes of the CP at the NUTS 2 disaggregation level.

Comparing the estimated ranges of $Q_{i, t}$ values, which condition different growth outcomes of the CP (see Table 3) with the distribution of estimated $Q_{i, t}$ values over 2007-2013 programming period (see Figure A2 in Appendix C.3.), we can conclude that (i) insignificant growth outcomes of the $C P$ were in almost all regions of Romania, except for a few with untypically high (for a given country) $Q_{i, t}$ values, in half the regions of Bulgaria and a few regions of Italy and Hungary with the extremely low (for a given country) $Q_{i, t}$ values; (ii) positive and significant growth outcomes of the CP were in all other countries/regions.

Our findings are in line with [39] who also found that although growth over 2007-2013 was negative, correlation between cohesion payments and growth was positive, and with those of [7] who 
revealed the positive significant growth outcomes over the 2007-2013 programming period in all NUTS 1 and 2 level regions in Portugal, Spain, Greece, Ireland, Belgium, France, Finland, Germany, Luxembourg, the Netherlands, Sweden, and the UK.

Comparing the 2000-2006 and 2007-2013 programming periods we, similarly to [3], can conclude that the CP for 2007-2013 had a more significant positive impact on economic and productivity growth. These facts allow us to argue that the estimated effect differs according to the programming period and suggests an improvement of the CP efficiency for 2007-2013 when compared to the previous programming period. Moreover, the positive influence of the $\mathrm{CP}$ is stronger in the regions with better institutional environment. This reveals a potential paradox of the $\mathrm{CP}$ that works better in the relatively more developed regions (which are also characterised as having a better institutional environment) compared to smaller (although still positive) gains for the most disadvantaged areas of the EU. This finding is also in line with $[29,39]$.

Figure 3 shows the significance and direction of the conditional beta-convergence that is mediated by the $\mathrm{CP}$, institutional quality, and their interaction in terms of per capita GDP and productivity at the NUTS 2 and 3 disaggregation level over the 2000-2006 programming period.

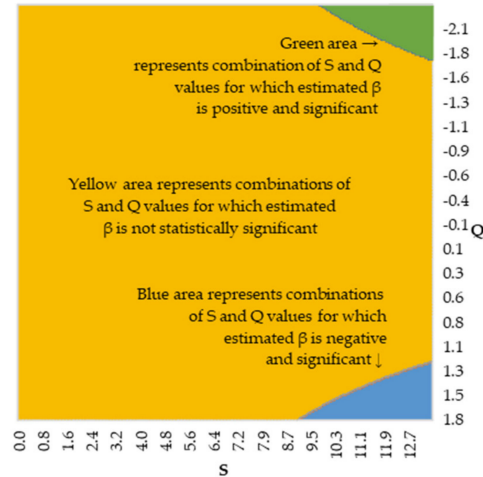

(a)

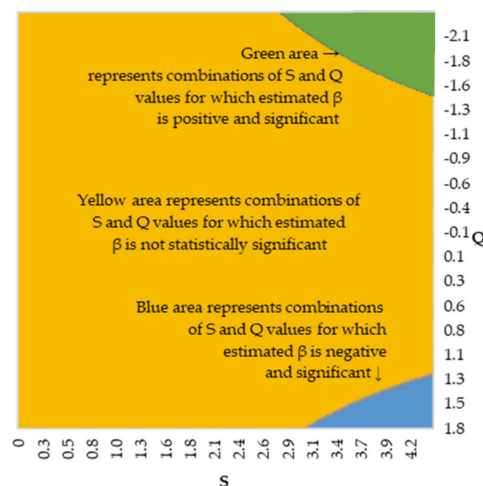

(c)

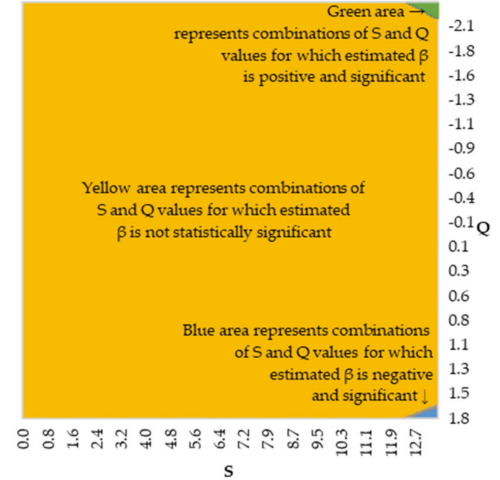

(b)

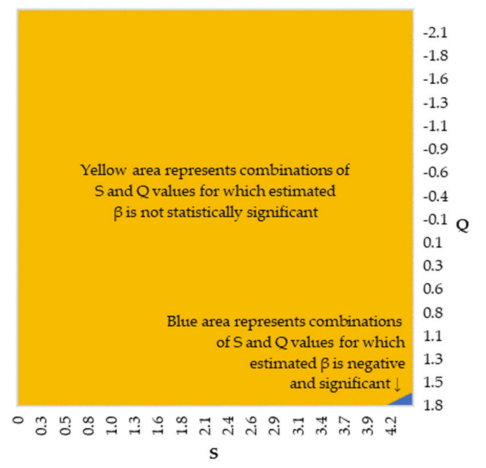

(d)

Figure 3. Significance and sign of the estimated slope coefficients of $g r_{i, t}$ on $Y_{i, t-1}$ according to the specific combination of values for $Q_{i, t}$ and $S_{i, t}$ over the 2000-2006 programming period, i.e., significance and sign of the conditional beta-convergence (or simply ' $\beta{ }^{*} 100^{\prime}$ in a figure) mediated by CP and institutional quality. (a) Represents convergence outcomes of the CP in terms of per capita GDP at the NUTS 3 disaggregation level. (b) Represents convergence outcomes of the CP in terms of productivity at the NUTS 3 disaggregation level. (c) Represents convergence outcomes of the CP in terms of per capita GDP at the NUTS 2 disaggregation level. (d) Represents convergence outcomes of the CP in terms of productivity at the NUTS 2 disaggregation level. 
The estimates show that the vast majority of combinations for $Q_{i, t}$ and $S_{i, t}$ over the observed range of values led to the insignificant convergence outcomes of the $\mathrm{CP}$. We observe significant outcomes just if $\mathrm{CP}$ commitments are extremely intensive. Moreover, significant beta-convergence occurs in case of a relatively very favourable institutional environment and significant beta-divergence in case of a relatively very unfavourable institutional environment. The same is true for both dependent variables and both disaggregation levels under consideration. This suggests that a higher intensity of $\mathrm{CP}$ commitments positively mediates the significance of the $\mathrm{CP}$ convergence outcomes, whereas the institutional environment mediates whether there are positive or negative convergence outcomes. We find that the statistically significant negative convergence outcomes of the CP over the 2000-2006 programming period were in Greece, which is characterised by a high intensity of CP funding and low institutional quality. No region had a combination of high $Q_{i, t}$ and $S_{i, t}$ values over the 2000-2006 programming period that would fall into the range of a statistically significant positive impact on convergence.

Figure 4 shows the significance direction and speed of the conditional beta-convergence in terms of per capita GDP and productivity at the NUTS 2 and 3 disaggregation level over the 2007-2013 programming period, which is mediated by the $\mathrm{CP}$, institutional quality, and their interaction.

The estimates suggest that, compared with the previous programming period, the number of observed combinations of values for $Q_{i, t}$ and $S_{i, t}$, which led to the significant convergence outcomes of the $\mathrm{CP}$, is much bigger. The estimates also show that the statistically significant estimated slope coefficients of $g r_{i, t \rightarrow T}$ on $Y_{i, t}$ are always negative, i.e., no observed combination of values for $Q_{i, t}$ and $S_{i, t}$ led to conditional beta-divergence. This suggests that CP induced convergence in terms of per capita GDP and productivity in a much bigger number of EU regions over 2007-2013 compared to the 2000-2006 programming period. Furthermore, the higher intensity of CP commitments and a more favourable institutional environment generate a bigger (in absolute terms) $\beta$ coefficient, i.e., leads to faster convergence.

We find that $\mathrm{CP}$ had a minor positive impact on convergence for core regions in Austria, Belgium, Denmark Finland, France, Germany, Ireland, the Netherlands, Sweden and the UK, since their funding intensity was relatively low while the development level and the level of the institutional quality were among the highest in the EU. Less developed regions in the abovementioned countries, which were more intensively funded and had a high level on institutional quality, experienced one of the most fruitful convergence outcomes of the $\mathrm{CP}$ among the EU regions. The weak convergence of just a few regions of Hungary, Romania, Italy, Portugal, Greece and Spain was positively affected by the CP and it was due to the extremely high level of funding intensity despite the low level of institution quality. The rest of the regions in these countries experienced the statistically insignificant convergence outcomes of the $\mathrm{CP}$, since a low level of funding intensity did not offset failures due to low-quality institutional environment. Regions of Croatia, the Czech Republic, Estonia, Latvia, Lithuania, Poland, Slovakia and Slovenia, despite their mid-level institutional environment, were experiencing the average convergence outcomes of the $\mathrm{CP}$ due to relatively intense funding. 


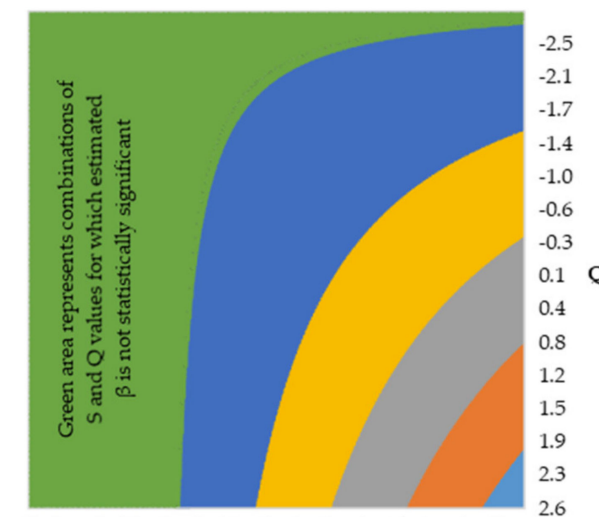

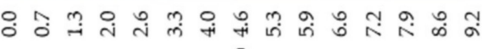

Values of a statistically $\square-0.14-0.12 \quad \square-0.12-0.1 \quad \square-0.1-0.08$ significant estimated $\beta \quad \square-0.08-0.06 \quad \square-0.06-0.04 \quad \square-0.04-0.03$

(a)

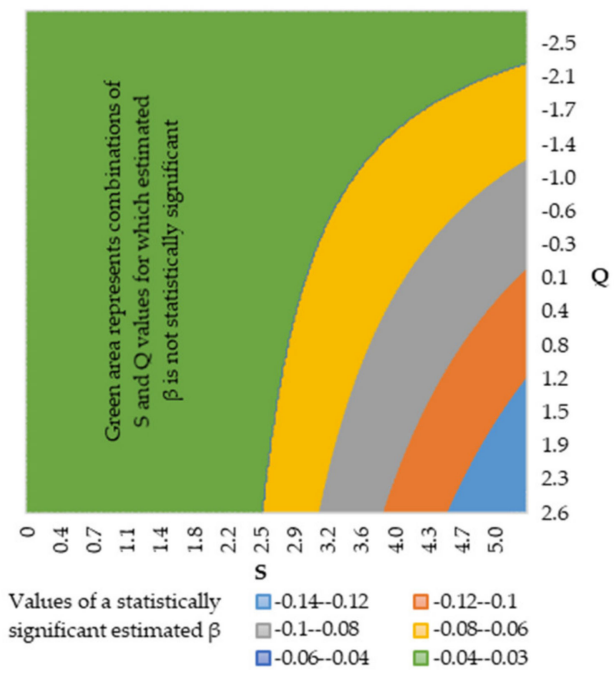

(c)

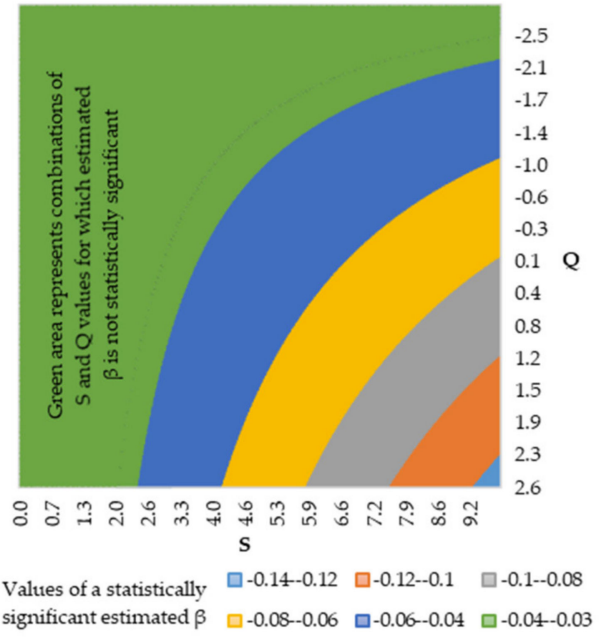

(b)

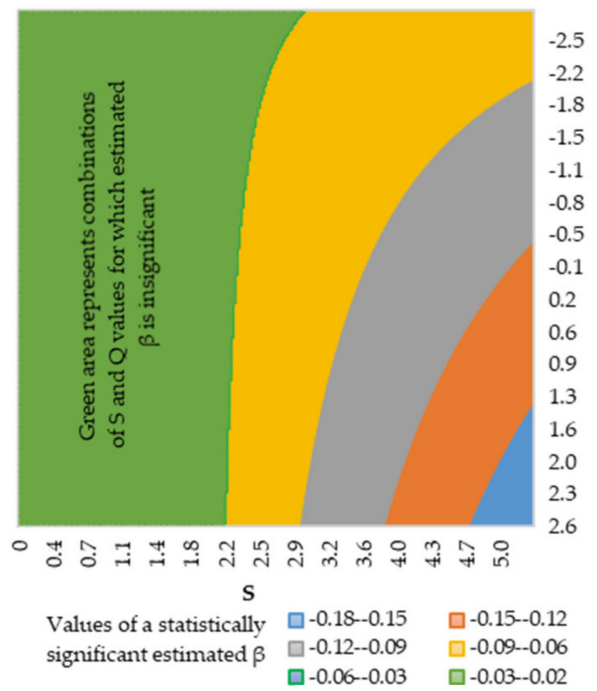

(d)

Figure 4. Significance, sign, and size of the estimated slope coefficients of $g r_{i, t}$ on $Y_{i, t-1}$ according to the specific combination of values for $Q_{i, t}$ and $S_{i, t}$ over the 2007-2013 programming period, i.e., significance, sign, and speed of the conditional beta-convergence (or simply ' $\beta^{*} 100^{\prime}$ in the figure) mediated by $\mathrm{CP}$ and institutional quality. (a) Represents convergence outcomes of the $\mathrm{CP}$ in terms of per capita GDP at the NUTS 3 disaggregation level. (b) Represents convergence outcomes of the CP in terms of productivity at the NUTS 3 disaggregation level. (c) Represents convergence outcomes of the CP in terms of per capita GDP at the NUTS 2 disaggregation level. (d) Represents convergence outcomes of the CP in terms of productivity at the NUTS 2 disaggregation level.

The estimation results show that $\mathrm{CP}$ and institutional quality act, at some point, as the substituting mediating factors of conditional beta-convergence, i.e., the same $\beta$ is estimated, i.e., the same speed of convergence can be reached in regions with a low intensity of CP commitments and favourable institutional environment, as well as in the regions with a high intensity of CP commitments and relatively unfavourable institutional environment. This reveals there is no potential paradox in the $\mathrm{CP}$ that generates the same convergence outcomes in the relatively less developed regions (that are also characterised as having a less favourable institutional environment) if they are more intensively financed as in the relatively more developed regions (that are also characterised as having more favourable institutional environment) if they are less intensively financed. It can be added that the 
substituting effect between the $\mathrm{CP}$ and institutional quality is diminishing, i.e., substitution between these two mediating factors has its limits.

Finding the evidence of a substituting effect does not mean that CP funding (money) can buy institutional quality (efficiency), i.e., that the two are interchangeable. We do not propose for policymakers to direct more CP transfers to poor-IQ regions as a form of "reward" for the less capable and/or, presumably, more corrupt regions. In light of our other findings, in which CP and IQ are shown as complementary for growth (their interaction term is positive and significant in both the programming periods), the policy advice is that CP transfers should be directed towards "good governance" regions. Moreover, if CP funds are directed to poor-IQ regions, these, in the first place, should be used to improve the overall institutional quality and only after that used for other purposes. The substitution effect that we find means that the same convergence effect could be reached by transferring more funds to regions with a relatively poor IQ as by transferring fewer funds to regions with a relatively good IQ, and suggests that a good IQ increases the efficiency of the funding. Even more, it suggests that CP transfers to poor-IQ regions create an effect of a dummy convergence by only increasing regional GDP as an additional expenditure in the region, which disappears when the funding ends, since it does not have a long-lasting effect on growth.

\section{Conclusions}

Our paper contributes to the methodological approaches used to estimate the outcomes of the CP by augmenting a traditional conditional beta-convergence model with a 3-way multiplicative term. We have shown that this specification could be used not only to examine the effect of the mediating factors on the growth outcomes of the $\mathrm{CP}$ but also on the convergence outcomes. Contrary to previously applied specifications with a 2-way multiplicative term, which only allowed to indirectly estimate the effect of the $\mathrm{CP}$ on convergence, our approach contributes to the direct estimation of the variability of the conditional beta-convergence coefficient, which depends on the intensity of the $\mathrm{CP}$ and a factor that could mediate the convergence outcomes of the CP. The suggested specification of the conditional beta-convergence model and the computation of conditional standard errors could contribute to the analysis of any mediating factor proxied by an interval/ratio variable.

Our empirical analysis aimed to estimate the mediating effect of institutional quality (which we assume is a crucial factor and connects other ones that mediate the outcomes of the $\mathrm{CP}$ ) contributes to the evaluation of the growth and convergence outcomes of the $\mathrm{CP}$, especially at the previously less analysed NUTS 3 level. Our empirical estimates based on conditional slopes and conditional standard errors contribute to explanting the sources of the heterogenous finding by previous research, which analyse different groups of regions and/or countries. We have shown that by computing the conditional marginal effects and their standard errors, we can find the positive and negative as well as significant and insignificant outcomes of the $\mathrm{CP}$ for different countries and/or regions.

The stability of the estimates (for all interaction terms) across spatial scales (levels of disaggregation) and across the dependent variables and programming periods is vital to robustly conclude that institutional quality plays a crucial role in determining the growth and convergence outcomes of the $\mathrm{CP}$, which over the 2007-2013 programming period was much more successful in boosting growth and convergence compared to the previous one.

Our findings support the view that the direction, size, and significance of the effect of the CP commitment intensity on growth are conditional, i.e., a more significant positive effect is more plausible in regions with a more favourable institutional environment and vice versa, and that a significant effect is more likely to occur in regions where institutional quality is far from being average. These findings coincide with previous research that reveals a potential paradox in the CP that works better in the relatively more developed regions, which are not the main target of the $\mathrm{CP}$ compared to the most disadvantaged areas of the EU primarily targeted by the CP.

Considering the convergence outcomes, we have found that both the $\mathrm{CP}$ and institutional quality positively condition convergence in terms of per capita GDP and productivity. We have shown 
that the more intense $\mathrm{CP}$ commitments accelerate convergence, and if the institutional environment is favourable, this acceleration is even more significant. Furthermore, both act like substituting the mediating factors of the conditional beta-convergence with the diminishing marginal rate of substitution. This finding suggests that a higher intensity of cohesion payments could at some point compensate for an unfavourable institutional environment that hinders regional convergence and refutes the paradox of the $\mathrm{CP}$.

Nevertheless, a higher intensity of $\mathrm{CP}$ commitments in the most disadvantaged (with the relatively unfavourable institutional environment) areas of the EU, aiming to speed-up the catch-up process, is not justified. Concerning the CP dilemmas: how much to spend and where, whether to "help the needy" or to "reward the able", or whether to favour growth or convergence, our suggestions are as follows: (i) although boosting growth does not necessarily mean speeding-up the convergence, directing more $\mathrm{CP}$ funds towards regions with good IQ would help to achieve both goals. However, the primary focus should be on the convergence outcome; and (ii) $\mathrm{CP}$ funds should first be directed to improve IQ in the least developed regions and only later for other purposes.

The main limitations of our study that could be addressed in future research, using the developed specifications, are related to (i) assumptions made to quantify institutional quality at the NUTS 3 disaggregation level; (ii) the examination of the effect of other mediating factors on the outcomes of the $\mathrm{CP}$; and (iii) testing the sensitivity of the findings to different estimation strategies. For example, since the 2007-2013 period covers the huge crisis in the Eurozone, which was highly asymmetric across countries and regions, many regions experienced negative growth rates. Perhaps an estimation split, running the model separately for cases of positive growth and cases of negative growth, would provide more information about whether the estimated effect of the $\mathrm{CP}$ is stronger because of "more policy effectiveness" or rather because of the nature of the growth-rate evolutions across space during the Eurozone crisis. The discussion about the country-cases and different country experiences also could be enriched by interacting the policy variables with a set of country fixed-effects.

Author Contributions: Conceptualization, M.B., A.M.-̌̌. and K.M.; methodology, M.B.; formal analysis, M.B.; resources, A.M.-Š. and K.M.; data collection M.B. and K.M., theoretical analysis, A.M.-̌̌. and K.M.; writing-original draft preparation, M.B., A.M.-Š. and K.M.; writing-review and editing, M.B., A.M.-Š. and K.M.; visualization, M.B. All authors have read and agreed on the published version of the manuscript.

Funding: This research was funded by the Research Council of Lithuania under agreement No. S-MIP-17-114.

Conflicts of Interest: The authors declare no conflict of interest. 


\section{Appendix A}

Table A1. Main results of estimations of the CP's outcomes in previous studies.

\begin{tabular}{|c|c|c|c|c|c|c|c|}
\hline Research by & Covered Period & Units & $\begin{array}{c}\text { Econometric } \\
\text { Method Applied* }\end{array}$ & Outcome Variable & Overall Impact & Conditioning Factors & Interaction Variable \\
\hline $\begin{array}{l}\text { Kutan and } \\
\text { Yigit [15] }\end{array}$ & 1980-2004 & $\begin{array}{l}\text { EU-5 quarterly } \\
\text { data }\end{array}$ & $\begin{array}{l}\text { Structural break } \\
\text { test, DEA }\end{array}$ & $\begin{array}{l}\text { Productivity, } \\
\text { economic growth, } \\
\text { convergence }\end{array}$ & $\begin{array}{l}\text { Positive, } \\
\text { significant }\end{array}$ & - & - \\
\hline $\begin{array}{l}\text { Falk and } \\
\text { Sinabell [28] }\end{array}$ & 1995-2004 & $\begin{array}{l}1084 \text { NUTS-3 } \\
\text { regions (EU-15) }\end{array}$ & OLS, WLSQ & Economic growth & $\begin{array}{c}\text { Positive, } \\
\text { significant }\end{array}$ & - & - \\
\hline $\begin{array}{l}\text { Mohl and } \\
\text { Hagen [65] }\end{array}$ & 1995-2005 & $\begin{array}{c}124 \\
\begin{array}{c}\text { NUTS-1/NUTS-2 } \\
\text { regions }\end{array}\end{array}$ & LSDV, GMM & Economic growth & $\begin{array}{l}\text { Positive, } \\
\text { significant }\end{array}$ & - & - \\
\hline $\begin{array}{l}\text { Wostner and } \\
\text { Šlander [66] }\end{array}$ & $\begin{array}{l}\text { 1990-1993, } \\
\text { 1994-1999, } \\
\text { 2000-2006 }\end{array}$ & $\begin{array}{c}\text { EU-15, } \\
\text { Country-level }\end{array}$ & $\mathrm{FE}$ & STREXP ** & $\begin{array}{l}\text { Positive, } \\
\text { significant }\end{array}$ & - & \\
\hline Becker et al. [67] & $\begin{array}{l}1989-1993 \\
1994-1999, \\
2000-2006\end{array}$ & $\begin{array}{l}\text { NUTS2 (193-285) } \\
\text { and NUTS3 } \\
(1015-1213) \\
\text { regions (EU-25) }\end{array}$ & DiD, RDD & $\begin{array}{l}\text { Economic and } \\
\text { employment } \\
\text { growth }\end{array}$ & $\begin{array}{l}\text { Positive, } \\
\text { significant }\end{array}$ & - & - \\
\hline $\begin{array}{l}\text { Mohl and } \\
\text { Hagen [68] }\end{array}$ & 2000-2006 & $\begin{array}{c}126 \\
\text { NUTS-1/NUTS-2 } \\
\text { regions EU-6 }\end{array}$ & GMM & Economic growth & $\begin{array}{l}\text { Positive, } \\
\text { significant }\end{array}$ & - & - \\
\hline $\begin{array}{l}\text { Varga and } \\
\text { Veld [69] }\end{array}$ & 2000-2006 & $\begin{array}{c}\text { EU-16 } \\
\text { Country-level }\end{array}$ & $\begin{array}{l}\text { DSGE model with } \\
\text { semi-endogenous } \\
\text { growth }\end{array}$ & Economic growth & $\begin{array}{c}\text { Positive, } \\
\text { significant in less } \\
\text { developed regions }\end{array}$ & - & - \\
\hline Gómez-García et al. [37] & $2000-2006$ & $\begin{array}{l}46 \text { NUTS } 1 \text { EU-10 } \\
\text { regions }\end{array}$ & $\begin{array}{l}\text { DEA and SFM, } \\
\text { correlation } \\
\text { analysis }\end{array}$ & $\begin{array}{l}\text { Employment and } \\
\text { productivity }\end{array}$ & $\begin{array}{c}\text { Positive, } \\
\text { significant on } \\
\text { employment, } \\
\text { insignificant on } \\
\text { productivity }\end{array}$ & Geographical location & $\begin{array}{l}\text { An interaction term of } \\
\text { ESF and EAGGF }\end{array}$ \\
\hline
\end{tabular}


Table A1. Cont.

\begin{tabular}{|c|c|c|c|c|c|c|c|}
\hline Research by & Covered Period & Units & $\begin{array}{c}\text { Econometric } \\
\text { Method Applied* }\end{array}$ & Outcome Variable & Overall Impact & Conditioning Factors & Interaction Variable \\
\hline $\begin{array}{l}\text { Kyriacou and } \\
\text { Roca-Sagalés [16] }\end{array}$ & $\begin{array}{l}\text { 1994-1999, } \\
\text { 2000-2006 }\end{array}$ & $\begin{array}{l}14 \text { EU countries } \\
\text { Country-level }\end{array}$ & FGLS, SUR & Convergence & $\begin{array}{l}\text { Positive, } \\
\text { significant }\end{array}$ & $\begin{array}{l}\text { Institutional quality, } \\
\text { economic openness, } \\
\text { human capital, ethnic } \\
\text { segregation }\end{array}$ & - \\
\hline Becker et al. [17] & $\begin{array}{l}\text { 1989-1993, } \\
\text { 1994-1999, } \\
2000-2006\end{array}$ & $\begin{array}{l}\text { 186-251 NUTS } 2 \\
\text { regions (EU-25) }\end{array}$ & RDD, HLATE & Economic growth & $\begin{array}{c}\text { Positive, } \\
\text { significant at } \\
\text { conventional } \\
\text { levels }\end{array}$ & $\begin{array}{l}\text { Quality of institutions, } \\
\text { the level of education }\end{array}$ & $\begin{array}{l}\text { An interaction term of } \\
\text { human capital, } \\
\text { government quality } \\
\text { and eligibility for } \\
\text { Objective } 1 \text { payments }\end{array}$ \\
\hline Bouayad-Agha et al. [36] & ] 1980-2005 & $\begin{array}{c}143 \text { EU-14- } \\
\text { NUTS-1/NUTS-2 } \\
\text { regions }\end{array}$ & GMM & Economic growth & $\begin{array}{l}\text { Positive, } \\
\text { significant }\end{array}$ & Spatial interactions & - \\
\hline Pellegrini et al. [13] & $\begin{array}{l}\text { 1994-1999, } \\
\text { 2000-2006 }\end{array}$ & $\begin{array}{l}\text { NUTS-2 regions } \\
\quad \text { (EU-15) }\end{array}$ & RDD & $\begin{array}{l}\text { Economic growth, } \\
\text { convergence }\end{array}$ & $\begin{array}{l}\text { Positive, } \\
\text { significant }\end{array}$ & - & $\begin{array}{c}\text { An interaction } \\
\text { between the indicator } \\
\text { variable for Objective } \\
1 \text { treatment and the } \\
\text { level of per capita } \\
\text { GDP in PPS }\end{array}$ \\
\hline $\begin{array}{l}\text { Rodriguez-Pose } \\
\text { and Novak [26] }\end{array}$ & $\begin{array}{l}\text { 1994-1999, } \\
\text { 2000-2006 }\end{array}$ & $\begin{array}{c}133(\text { EU15) } \\
\text { NUTS-1/NUTS-2 } \\
\text { regions }\end{array}$ & FE & Economic growth & $\begin{array}{l}\text { Positive, } \\
\text { significant }\end{array}$ & - & $\begin{array}{l}\text { An interaction term of } \\
\text { Structural Funds } \\
\text { expenditure and the } \\
\text { level of economic } \\
\text { development of a } \\
\text { region in comparison } \\
\text { with the country } \\
\text { average }\end{array}$ \\
\hline Accetturo et al. [70] & 2000-2006 & NUTS-2 level & RDD & $\begin{array}{l}\text { Local endowments } \\
\text { of trust and } \\
\text { cooperation }\end{array}$ & $\begin{array}{l}\text { Negative, } \\
\text { significant }\end{array}$ & - & - \\
\hline $\begin{array}{l}\text { Fratesi and } \\
\text { Perucca [29] }\end{array}$ & 2006-2010 & $\begin{array}{l}108 \text { NUTS-3 } \\
\text { regions of CEE }\end{array}$ & OLS & Economic growth & $\begin{array}{l}\text { Positive, } \\
\text { significant }\end{array}$ & Territorial capital & - \\
\hline
\end{tabular}


Table A1. Cont.

\begin{tabular}{|c|c|c|c|c|c|c|c|}
\hline Research by & Covered Period & Units & $\begin{array}{c}\text { Econometric } \\
\text { Method Applied* }\end{array}$ & Outcome Variable & Overall Impact & Conditioning Factors & Interaction Variable \\
\hline $\begin{array}{l}\text { Florio and } \\
\text { Moretti [64] }\end{array}$ & $2000-2006$ & $\begin{array}{l}70 \text { NUTS 1/2 } \\
\text { regions (EU-3), } \\
\text { industry level }\end{array}$ & FE, OLS & $\begin{array}{l}\text { Economic and } \\
\text { employment } \\
\text { growth, } \\
\text { convergence }\end{array}$ & $\begin{array}{l}\text { Positive, } \\
\text { significant on } \\
\text { employment, } \\
\text { insignificant on } \\
\text { growth }\end{array}$ & - & $\begin{array}{l}\text { An interaction term of } \\
\text { average annual } \\
\text { business support that } \\
\text { is financed by SF and } \\
\text { the initial share of } \\
\text { employment of } \\
\text { industry }\end{array}$ \\
\hline $\begin{array}{l}\text { Ciani and de } \\
\text { Blasio [1] }\end{array}$ & 2008-2013 & $\begin{array}{l}325 \text { local labour } \\
\text { markets, Southern } \\
\text { Italy }\end{array}$ & DiD & $\begin{array}{l}\text { Employment, } \\
\text { population, house } \\
\text { prices }\end{array}$ & $\begin{array}{l}\text { Insignificant effect } \\
\text { of cumulated } \\
2008-2013 \\
\text { payments, positive } \\
\text { significant of } \\
\text { 2009-10, 2012-13 } \\
\text { payments on } \\
\text { employment }\end{array}$ & - & $\begin{array}{l}\text { Interactions with the } \\
\text { time trend and } \\
\text { unemployment rate, } \\
\text { the flow of payments } \\
\text { and the indicators for } \\
\text { slackness in housing } \\
\text { and labour market }\end{array}$ \\
\hline $\begin{array}{l}\text { Coppola and } \\
\text { Destefanis [4] }\end{array}$ & $\begin{array}{l}\text { 1989-1993, } \\
1994-1999, \\
2000-2006\end{array}$ & $\begin{array}{c}20 \text { Italian } \\
\text { administrative } \\
\text { regions, sectoral } \\
\text { level }\end{array}$ & $\begin{array}{c}\text { FDH-VP } \\
\text { Approach and FE }\end{array}$ & $\begin{array}{l}\text { TFP, capital } \\
\text { accumulations and } \\
\text { employment }\end{array}$ & $\begin{array}{c}\text { Positive, } \\
\text { significant on TFP; } \\
\text { insignificant on } \\
\text { capital } \\
\text { accumulations and } \\
\text { employment }\end{array}$ & - & $\begin{array}{l}\text { Systematic differences } \\
\text { across time and } \\
\text { regions }\end{array}$ \\
\hline $\begin{array}{l}\text { Crescenzi and } \\
\text { Giua [39] }\end{array}$ & $\begin{array}{l}1994-1999 \\
2000-2006 \\
2007-2013\end{array}$ & $\begin{array}{c}139 \text { EU-12 NUTS } 1 \\
\text { and NUTS } 2 \\
\text { regions }\end{array}$ & $\begin{array}{l}\text { FE, Quantile } \\
\text { Regression }\end{array}$ & Economic growth & $\begin{array}{c}\text { Positive, } \\
\text { significant }\end{array}$ & $\begin{array}{l}\text { Territorial conditions } \\
\text { (demographics, } \\
\text { productive structure, } \\
\text { labour market, } \\
\text { innovative capacity } \\
\text { and infrastructure } \\
\text { endowment) }\end{array}$ & - \\
\hline Pinho et al. [7] & $\begin{array}{l}1995-1999 \\
2000-2006 \\
2007-2009\end{array}$ & $\begin{array}{l}92 \text { EU } 12 \text { NUTS } 1 \\
\text { and NUTS } 2 \\
\text { regions }\end{array}$ & FE & Economic growth & $\begin{array}{c}\text { Positive, } \\
\text { significant }\end{array}$ & $\begin{array}{l}\text { Income, human } \\
\text { capital, innovation }\end{array}$ & $\begin{array}{c}\text { An interaction } \\
\text { between funds and } \\
\text { income (also the initial } \\
\text { level of income), } \\
\text { human capital and } \\
\text { innovations }\end{array}$ \\
\hline
\end{tabular}


Table A1. Cont.

\begin{tabular}{|c|c|c|c|c|c|c|c|}
\hline Research by & Covered Period & Units & $\begin{array}{c}\text { Econometric } \\
\text { Method Applied* }\end{array}$ & Outcome Variable & Overall Impact & Conditioning Factors & Interaction Variable \\
\hline Pinho et al. [8] & 1995-2009 & $\begin{array}{l}137 \text { European } \\
\text { regions }\end{array}$ & FE & Economic growth & $\begin{array}{c}\text { Positive, } \\
\text { significant }\end{array}$ & $\begin{array}{l}\text { Income, human } \\
\text { capital, innovation }\end{array}$ & $\begin{array}{c}\text { An interaction } \\
\text { between funds and } \\
\text { income (also the initia } \\
\text { level of income), } \\
\text { human capital and } \\
\text { innovations }\end{array}$ \\
\hline $\begin{array}{l}\text { Rodriguez-Pose } \\
\text { and Garcilazo [18] }\end{array}$ & 1996-2007 & $\begin{array}{c}169 \text { European } \\
\text { NUTS-1/NUTS-2 } \\
\text { regions }\end{array}$ & FE & Economic growth & $\begin{array}{c}\text { Positive, } \\
\text { significant }\end{array}$ & $\begin{array}{l}\text { Quality of } \\
\text { government, } \\
\text { interaction between } \\
\text { the CF and quality of } \\
\text { government }\end{array}$ & $\begin{array}{l}\text { The interaction term } \\
\text { between the indicator } \\
\text { of the quality of } \\
\text { government and the } \\
\text { per capita investments } \\
\text { under the structural } \\
\text { and cohesion policy } \\
\text { framework }\end{array}$ \\
\hline Dotti [5] & 2000-2006 & $\begin{array}{l}\text { EU-5 NUTS } 1 \text { and } \\
\text { NUTS } 2 \text { regions }\end{array}$ & $\begin{array}{l}\text { Correlation } \\
\text { analysis }\end{array}$ & Productivity & $\begin{array}{c}\text { Negative, } \\
\text { significant or } \\
\text { insignificant } \\
\text { depending on } \\
\text { political behaviour }\end{array}$ & Political behaviour & - \\
\hline $\begin{array}{l}\text { Eberle and } \\
\text { Brenner [41] }\end{array}$ & 2002-2011 & $\begin{array}{l}402 \text { German } \\
\text { administrative } \\
\text { districts }\end{array}$ & GMM & Economic growth & $\begin{array}{c}\text { Positive or } \\
\text { negative } \\
\text { depending on the } \\
\text { intervention area, } \\
\text { significant (in } \\
\text { some cases not } \\
\text { significant) }\end{array}$ & Innovation level & - \\
\hline $\begin{array}{l}\text { European } \\
\text { Commission [71] }\end{array}$ & $\begin{array}{l}\text { 1994-1999, } \\
2000-2006, \\
2007-2013\end{array}$ & $\begin{array}{c}263 \text { NUTS } 2 \text { EU-27 } \\
\text { regions }\end{array}$ & RDD & Economic growth & $\begin{array}{l}\text { Positive, } \\
\text { significant }\end{array}$ & Payments intensity & $\begin{array}{c}\text { The interaction } \\
\text { between intensity and } \\
\text { Dummy Treatment, } \\
\text { intensity Squared and } \\
\text { Dummy Treatment, } \\
\text { intensity Cubic and } \\
\text { Dummy Treatment }\end{array}$ \\
\hline
\end{tabular}


Table A1. Cont.

\begin{tabular}{|c|c|c|c|c|c|c|c|}
\hline Research by & Covered Period & Units & $\begin{array}{c}\text { Econometric } \\
\text { Method Applied* }\end{array}$ & Outcome Variable & Overall Impact & Conditioning Factors & Interaction Variable \\
\hline Maynou et al. [9] & 1990-2010 & $\begin{array}{c}174 \text { NUTS } 2 \text { EU-17 } \\
\text { regions }\end{array}$ & $\begin{array}{l}\text { Spatio-temporal } \\
\text { econometric } \\
\text { model }\end{array}$ & $\begin{array}{l}\text { Economic growth } \\
\text { and convergence }\end{array}$ & $\begin{array}{l}\text { Positive, } \\
\text { significant }\end{array}$ & - & - \\
\hline $\begin{array}{l}\text { Pellegrini and } \\
\text { Cerqua [10] }\end{array}$ & $\begin{array}{l}\text { 1994-1999, } \\
2000-2006, \\
2007-2013\end{array}$ & $\begin{array}{l}208 \text { NUTS-2 } \\
\text { regions (EU-15) }\end{array}$ & $\begin{array}{c}\text { Counterfactual } \\
\text { causal analysis } \\
\text { and RDD }\end{array}$ & Economic growth & $\begin{array}{l}\text { Positive, } \\
\text { significant }\end{array}$ & Payments intensity & $\begin{array}{l}\text { The interaction between } \\
\text { intensity (intensity } \\
\text { squared and intensity } \\
\text { cubic) and Dummy } \\
\text { Treatment }\end{array}$ \\
\hline $\begin{array}{l}\text { Bondonio and } \\
\text { Pellegrini [72] }\end{array}$ & $\begin{array}{l}\text { 1994-2006, } \\
2007-2011\end{array}$ & $\begin{array}{l}259 \text { EU-15, EU-27 } \\
\text { NUTS } 2\end{array}$ & PSM, GPS, RDD & Economic growth & $\begin{array}{c}\text { Positive, } \\
\text { significant }\end{array}$ & Payments intensity & - \\
\hline Host et al. [38] & 2000-2013 & $\begin{array}{c}\text { EU-27 } \\
\text { Country-level }\end{array}$ & $\begin{array}{l}\text { Pooled OLS, FE, } \\
\text { RE }\end{array}$ & Economic growth & $\begin{array}{c}\text { Positive, } \\
\text { significant in } \\
\text { countries with } \\
\text { high IQ, and } \\
\text { insignificant in } \\
\text { countries with low } \\
\text { IQ }\end{array}$ & Institutional quality & $\begin{array}{c}\text { The interaction between } \\
\text { the institutional quality } \\
\text { and the absorption of } \\
\text { EU funds. }\end{array}$ \\
\hline $\begin{array}{l}\text { Arbolino and } \\
\text { Boffardi [19] }\end{array}$ & 2007-2013 & $\begin{array}{l}24 \text { NUTS } 2 \text { Italian } \\
\text { regions }\end{array}$ & FE, RE & Economic growth & $\begin{array}{l}\text { Positive, } \\
\text { significant }\end{array}$ & $\begin{array}{l}\text { Per capita amount of } \\
\text { the payments made in } \\
\text { each region, the } \\
\text { Efficiency of Payment } \\
\text { index, the Quality of } \\
\text { local institutions }\end{array}$ & $\begin{array}{l}\text { The interaction between } \\
\text { per capita amount of the } \\
\text { payments made in each } \\
\text { region and the Efficiency } \\
\text { of Payment index, per } \\
\text { capita amount of the } \\
\text { payments made in each } \\
\text { region and the Quality } \\
\text { of local institutions }\end{array}$ \\
\hline Di Cataldo [2] & $\begin{array}{l}\text { 1994-1999, } \\
2000-2006, \\
2007-2013\end{array}$ & $\begin{array}{l}\text { Two UK NUTS-2 } \\
\text { regions: } 134 \text { wards } \\
\text { of Cornwall and } \\
\text { the } 94 \text { wards of } \\
\text { South Yorkshire }\end{array}$ & $\begin{array}{l}\text { Synthetic control } \\
\text { method, DiD }\end{array}$ & $\begin{array}{c}\text { Economic growth } \\
\text { and } \\
\text { unemployment }\end{array}$ & $\begin{array}{c}\text { Positive, } \\
\text { significant }\end{array}$ & $\begin{array}{c}\text { Loss of Objective } 1 \\
\text { status }\end{array}$ & $\begin{array}{l}\text { An interaction between } \\
\text { a dummy for wards } \\
\text { belonging to treated } \\
\text { regions and a dummy } \\
\text { referring to the } \\
\text { post-2000 period of } \\
\text { reference }\end{array}$ \\
\hline
\end{tabular}


Table A1. Cont.

\begin{tabular}{|c|c|c|c|c|c|c|c|}
\hline Research by & Covered Period & Units & $\begin{array}{c}\text { Econometric } \\
\text { Method Applied* }\end{array}$ & Outcome Variable & Overall Impact & Conditioning Factors & Interaction Variable \\
\hline $\begin{array}{l}\text { Gagliardi and } \\
\text { Percoco [11] }\end{array}$ & 2000-2006 & $\begin{array}{c}257 \text { NUTS-2 and } \\
1233 \text { NUTS-3 } \\
\text { regions (EU-15, } \\
\text { EU-10) }\end{array}$ & A fuzzy RDD, OLS & Economic growth & $\begin{array}{l}\text { Positive, } \\
\text { significant }\end{array}$ & $\begin{array}{l}\text { Degree of urbanisation } \\
\text { and distance from main } \\
\text { urban agglomerates }\end{array}$ & - \\
\hline Pontarollo [6] & 2000-2006 & $\begin{array}{c}\text { EU-15, } 202 \text { NUTS } \\
1 / 2 \text { regions }\end{array}$ & GAM, GLMs & $\begin{array}{l}\text { Economic and } \\
\text { productivity } \\
\text { growth }\end{array}$ & $\begin{array}{c}\text { Positive or } \\
\text { negative } \\
\text { depending on the } \\
\text { intervention area, } \\
\text { significant }\end{array}$ & - & - \\
\hline $\begin{array}{l}\text { Cerqua and } \\
\text { Pellegrini [58] }\end{array}$ & $\begin{array}{l}\text { 1994-1999, } \\
\text { 2000-2006 }\end{array}$ & $\begin{array}{c}208 \text { NUTS } 2 \text { EU-15 } \\
\text { regions }\end{array}$ & RDD & $\begin{array}{l}\text { Economic growth, } \\
\text { growth rate of real } \\
\text { GVA, the } \\
\text { employment } \\
\text { growth rate, the } \\
\text { labour } \\
\text { productivity } \\
\text { growth rate and } \\
\text { convergence }\end{array}$ & $\begin{array}{l}\text { Positive, } \\
\text { significant }\end{array}$ & Payments intensity & $\begin{array}{l}\text { The interaction between } \\
\text { intensity and Dummy } \\
\text { Treatment, intensity } \\
\text { Squared and Dummy } \\
\text { Treatment, intensity } \\
\text { Cubic and Dummy } \\
\text { Treatment }\end{array}$ \\
\hline Becker et al. [3] & $\begin{array}{l}1989-1993 \\
1994-1999 \\
2000-2006 \\
2007-2013\end{array}$ & $\begin{array}{l}\text { NUTS-2 regions } \\
(187 \text { in 1989-1993, } \\
209 \text { in 1994-1999, } \\
253 \text { in 2000-2006, } \\
\text { and 253 in } \\
2007-2013) \text { of } \\
\text { EU-25 }\end{array}$ & A fuzzy RDD & $\begin{array}{l}\text { Economic and } \\
\text { employment } \\
\text { growth, total } \\
\text { investment } \\
\text { intensity, public } \\
\text { investment } \\
\text { intensity }\end{array}$ & $\begin{array}{l}\text { Positive, } \\
\text { significant }\end{array}$ & $\begin{array}{c}\text { Loss of Objective } 1 \\
\text { status }\end{array}$ & $\begin{array}{l}\text { An interaction between } \\
\text { eligibility status and } \\
\text { government-bond-yields } \\
\text { spreads proxy of the } \\
\text { Financial and Economic } \\
\text { Crisis }\end{array}$ \\
\hline Piętak [12] & 1989-2016 & $\begin{array}{c}17 \text { Spanish NUTS } \\
2 \text { regions }\end{array}$ & $\begin{array}{l}\text { FDGMM, SGMM, } \\
\text { RE, FE }\end{array}$ & $\begin{array}{l}\text { Economic growth } \\
\text { and convergence }\end{array}$ & $\begin{array}{c}\text { Positive, } \\
\text { insignificant }\end{array}$ & - & - \\
\hline $\begin{array}{l}\text { Di Cataldo and } \\
\text { Monastiriotis [14] }\end{array}$ & 1994 to 2013 & $\begin{array}{l}37 \text { UK NUTS2 } \\
\text { regions }\end{array}$ & $\begin{array}{l}\text { LSDV (fixed } \\
\text { effects) }\end{array}$ & $\begin{array}{l}\text { Economic growth } \\
\text { and convergence }\end{array}$ & $\begin{array}{l}\text { Positive, } \\
\text { significant }\end{array}$ & - & $\begin{array}{l}\text { An interaction between } \\
\text { assignment into } \\
\text { Objective } 1 \text { status and } \\
\text { EU funds per capita }\end{array}$ \\
\hline
\end{tabular}




\section{Appendix B}

We will use classical definitions of variance and covariance:

$$
\begin{gathered}
\operatorname{var}(X)=M\left(X^{2}\right)-(M(X))^{2}, \\
\operatorname{cov}(X, Z)=M(X Z)-M(X) M(Z)=M(X-M(X))(Z-M(Z)) .
\end{gathered}
$$

Moreover, we will use a few properties of variance, covariance, and relationships between them:

$$
\begin{gathered}
\operatorname{var}(c X)=c^{2} \operatorname{var}(X), c-\text { const., } \\
\operatorname{var}(X+Z)=\operatorname{var}(X)+\operatorname{var}(Z)+2 \operatorname{cov}(X, Z), \\
\operatorname{cov}(c X, Z)=c \cdot \operatorname{cov}(X, Z), c-c \text { const., } \\
\operatorname{cov}(X, Z+W)=\operatorname{cov}(X, Z)+\operatorname{cov}(X, W),
\end{gathered}
$$

In order to simplify, we will not use multiplication signs, subscripts, and accents, i.e.,

$$
\operatorname{var}\left(\hat{b}_{1} \cdot S_{i, t} \cdot Q_{i, t}\right)=\operatorname{var}\left(b_{1} S Q\right) \text {. }
$$

The standard error for the estimated coefficient of conditional beta-convergence, which is mediated by $\mathrm{CP}(S)$ and institutional quality $(Q)$ and their interaction $(S Q)$, is

$$
\sigma_{\frac{\partial[g r]}{\partial[\ln (Y)]}}=\sqrt{\operatorname{var}\left(\beta+b_{1} S+b_{3} Q+b_{4} S Q\right)}
$$

We find that

$$
\begin{aligned}
& \operatorname{var}\left(\beta+b_{1} S+b_{3} Q+b_{4} S Q\right) \\
& =\operatorname{var}\left[\left(\beta+b_{1} S\right)+\left(b_{3}+b_{4} S\right) Q\right] \\
& =\operatorname{var}\left(\beta+b_{1} S\right)+\operatorname{var}\left[\left(b_{3}+b_{4} S\right) Q\right]+2 \operatorname{cov}\left[\beta+b_{1} S,\left(b_{3}+b_{4} S\right) Q\right] \\
& =\operatorname{var}(\beta)+S^{2} \operatorname{var}\left(b_{1}\right)+2 \operatorname{cov}\left(\beta, b_{1} S\right)+Q^{2} \operatorname{var}\left(b_{3}\right)+S^{2} Q^{2} \operatorname{var}\left(b_{4}\right) \\
& +2 \operatorname{cov}\left(b_{3} Q, b_{4} S Q\right)+2 \operatorname{cov}\left[\beta+b_{1} S, b_{3} Q+b_{4} S Q\right] \\
& =\operatorname{var}(\beta)+S^{2} \operatorname{var}\left(b_{1}\right)+2 \operatorname{cov}\left(\beta, b_{1} S\right)+Q^{2} \operatorname{var}\left(b_{3}\right)+S^{2} Q^{2} \operatorname{var}\left(b_{4}\right) \\
& +2 \operatorname{cov}\left(b_{3} Q, b_{4} S Q\right)+2 \operatorname{cov}\left(\beta, b_{3} Q+b_{4} S Q\right) \\
& +2 \operatorname{cov}\left(b_{1} S, b_{3} Q+b_{4} S Q\right) \\
& =\operatorname{var}(\beta)+S^{2} \operatorname{var}\left(b_{1}\right)+2 S \operatorname{cov}\left(\beta, b_{1}\right)+Q^{2} \operatorname{var}\left(b_{3}\right)+S^{2} Q^{2} \operatorname{var}\left(b_{4}\right) \\
& +2 S Q^{2} \operatorname{cov}\left(b_{3}, b_{4}\right)+2 Q \operatorname{cov}\left(\beta, b_{3}\right)+2 S Q \operatorname{cov}\left(\beta, b_{4}\right) \\
& +2 \operatorname{cov}\left(b_{1} S, b_{3} Q\right)+2 \operatorname{cov}\left(b_{1} S, b_{4} S Q\right) \\
& =\operatorname{var}(\beta)+S^{2} \operatorname{var}\left(b_{1}\right)+2 S \operatorname{cov}\left(\beta, b_{1}\right)+Q^{2} \operatorname{var}\left(b_{3}\right)+S^{2} Q^{2} \operatorname{var}\left(b_{4}\right) \\
& +2 S Q^{2} \operatorname{cov}\left(b_{3}, b_{4}\right)+2 Q \operatorname{cov}\left(\beta, b_{3}\right)+2 S Q \operatorname{cov}\left(\beta, b_{4}\right) \\
& +2 S Q \operatorname{cov}\left(b_{1}, b_{3}\right)+2 S^{2} Q \operatorname{cov}\left(b_{1}, b_{4}\right)
\end{aligned}
$$

Thus:

$$
\begin{aligned}
\sigma_{\frac{\partial[g r]}{\partial[h(Y)]}=} & {\left[\operatorname{var}(\beta)+S^{2} \operatorname{var}\left(b_{1}\right)+Q^{2} \operatorname{var}\left(b_{3}\right)+S^{2} Q^{2} \operatorname{var}\left(b_{4}\right)+2 S \operatorname{cov}\left(\beta, b_{1}\right)\right.} \\
& +2 Q \operatorname{cov}\left(\beta, b_{3}\right)+2 S Q \operatorname{cov}\left(\beta, b_{4}\right)+2 S Q \operatorname{cov}\left(b_{1}, b_{3}\right) \\
& \left.+2 S^{2} Q \operatorname{cov}\left(b_{1}, b_{4}\right)+2 S Q^{2} \operatorname{cov}\left(b_{3}, b_{4}\right)\right]^{\frac{1}{2}}
\end{aligned}
$$




\section{Appendix C}

\section{Appendix C.1}

To calculate economic growth, we used regional per capita GDP at constant prices and regional GVA per employee at constant prices to calculate productivity growth. All data were collected from Eurostat.

The primary source of the data to calculate economic growth was gross domestic product indicators (reg_eco10gdp), subsection for the gross domestic product (GDP) at current market prices by NUTS3 regions (nama_10r_3gdp). To correct the changes at price levels over time, we used the price index (implicit deflator), $2010=100$, Euro (PD10_EUR). To calculate per capita GDP, we used average annual population to calculate regional GDP data (thousand persons) by NUTS 3 regions (nama_10r_3popgdp).

The primary source of the data to calculate productivity growth was branch and household accounts (reg_eco10brch), subsection for gross value added (GVA) at basic prices by NUTS 3 regions (nama_10r_3gva). To correct the changes at price levels over time, we used the price index (implicit deflator), $2010=100$, Euro (PD10_EUR). To calculate GVA per worker, we use employment (thousand persons) by NUTS 3 regions (nama_10r_3empers).

Descriptive statistics of $Y_{i, t}$ and growth are presented in Table A2.

Table A2. Main descriptive statistics of growth and $Y_{i, t}$.

\begin{tabular}{|c|c|c|c|c|c|c|c|}
\hline & Period & Variable & NUTS & Average & Min. & Max. & Std. Dev. \\
\hline \multirow{8}{*}{ Growth, \% } & \multirow{4}{*}{ 2000-2006 } & per capita & 2 & 2.13 & -0.43 & 9.73 & 1.53 \\
\hline & & GDP & 3 & 1.84 & -3.04 & 10.45 & 1.70 \\
\hline & & GVA per & 2 & 1.60 & -1.55 & 7.36 & 1.47 \\
\hline & & employee & 3 & 1.49 & -3.73 & 12.49 & 1.64 \\
\hline & \multirow{4}{*}{ 2007-2013 } & per capita & 2 & -0.45 & -6.62 & 3.61 & 1.77 \\
\hline & & GDP & 3 & -0.26 & -8.42 & 7.20 & 1.99 \\
\hline & & GVA per & 2 & 0.23 & -5.12 & 5.09 & 1.47 \\
\hline & & employee & 3 & -0.14 & -7.77 & 9.93 & 1.70 \\
\hline \multirow{8}{*}{$Y$, Euro } & \multirow{4}{*}{ 2000-2006 } & per capita & 2 & 20,587 & 4624 & 115,382 & 17,500 \\
\hline & & GDP & 3 & 20,445 & 2567 & 225,934 & 17,488 \\
\hline & & GVA per & 2 & 42,702 & 9465 & 202,400 & 16,228 \\
\hline & & employee & 3 & 42,702 & 5540 & 437,136 & 16,016 \\
\hline & \multirow{4}{*}{ 2007-2013 } & per capita & 2 & 22,071 & 3299 & 143,200 & 18,388 \\
\hline & & GDP & 3 & 21,184 & 2527 & 319,976 & 18,851 \\
\hline & & GVA per & 2 & 43,739 & 6274 & 253,470 & 17,531 \\
\hline & & employee & 3 & 42,830 & 4530 & 589,482 & 17,607 \\
\hline
\end{tabular}

\section{Appendix C.2}

For both programming periods, we analysed the ERDF and CF commitments combined. For 2000-2006, the SWECO [73] database contains data at the NUTS 2 and 3 disaggregation levels for the Cohesion Fund, ERDF Objective 1, ERDF Objective 2, URBAN, and INTERREG IIIA commitments for all current EU MS, except Bulgaria, Romania, and Croatia. The total amount mapped in the database for NUTS 3 is 149.819 billion EUR, which is $93.5 \%$, and for NUTS 2 it is 156.174 billion EUR, which is $97.5 \%$ of the total CF and ERDF budget for 2000-2006. For 2007-2013, [74] the database contains cumulative commitments of both ERDF and CF programmes at the NUTS 2 and 3 levels for all $28 \mathrm{EU}$ countries and covers the convergence, regional competitiveness, employment as well as the European territorial cooperation objectives. The total amount mapped in the database for NUTS 3 is 200.193 billion EUR, which is $97.3 \%$, and for NUTS 2 it is 202.854 billion EUR, which is $98.6 \%$ of the total budget for 2007-2013. Descriptive statistics of $S_{i, t}$ are presented in Table A3. 
Table A3. Main descriptive statistics of $S_{i, t}$.

\begin{tabular}{lcccc}
\hline & \multicolumn{2}{c}{ 2000-2006 } & \multicolumn{2}{c}{ 2007-2013 } \\
\cline { 2 - 5 } & NUTS 2 & NUTS 3 & NUTS 2 & NUTS 3 \\
\hline $\begin{array}{l}\text { Total number of regions } \\
\text { mapped in databases }\end{array}$ & 260 & 1251 & 271 & 1342 \\
Number of ERDF and CF & 242 & 1007 & 271 & 1304 \\
recipients & 93.1 & 80.5 & 100 & 97.2 \\
\% of total & & & & \\
ERDF and CF commitments & 0.47 & 0.51 & 0.59 & 0.53 \\
intensity, i.e., $S_{i, t} \%$ & $9.1 \times 10^{-4}$ & $1.57 \times 10^{-4}$ & $6.11 \times 10^{-4}$ & $1.31 \times 10^{-5}$ \\
Mean & 4.44 & 13.51 & 5.37 & 9.84 \\
Min. & 0.71 & 0.89 & 0.94 & 1.03 \\
Max. & & & \\
Std. dev. & & & \\
\hline
\end{tabular}

\section{Appendix C.3}

Since the earliest data on EQI provided by the Quality of Government Institute are available for 2010 [67] and the second available period is 2013, following [18,75], we interpolated values for the programming periods under consideration. We conducted this by combining the data on EQI for NUTS 2 regions with the World Bank's World Governance Indicators, available at the national level across the EU. The assumptions for interpolation are the same as in the previous contributions: (i) regional variations at the NUTS 2 level in institutional quality within countries are relatively stable and (ii) variations at the national level are captured by the World Bank's World Governance Indicators. Details on how this indicator is calculated can be found in [76]. We used the EQI level estimated for the NUTS 2 regions to proxy institution quality across all NUTS 3 regions within a particular NUTS 2 region. Since the strategy to use NUTS2 EQI at the NUTS3 level creates clusters, we controlled them while the standard errors of the coefficients were estimated. Short descriptive statistics of $S_{i, t}$ are presented in Table A4.

Table A4. Main descriptive statistics of $Q_{i, t}$.

\begin{tabular}{ccccc}
\hline & \multicolumn{2}{c}{ 2000-2006 } & \multicolumn{2}{c}{ 2007-2013 } \\
\cline { 2 - 5 } & NUTS 2 & NUTS 3 & NUTS 2 & NUTS 3 \\
\hline Mean & 0.26 & 0.32 & 0.13 & 0.16 \\
Min. & -2.28 & -2.28 & -2.82 & -2.82 \\
Max. & 1.76 & 1.76 & 2.64 & 2.64 \\
Std. dev. & 0.82 & 0.80 & 0.95 & 0.94 \\
\hline
\end{tabular}




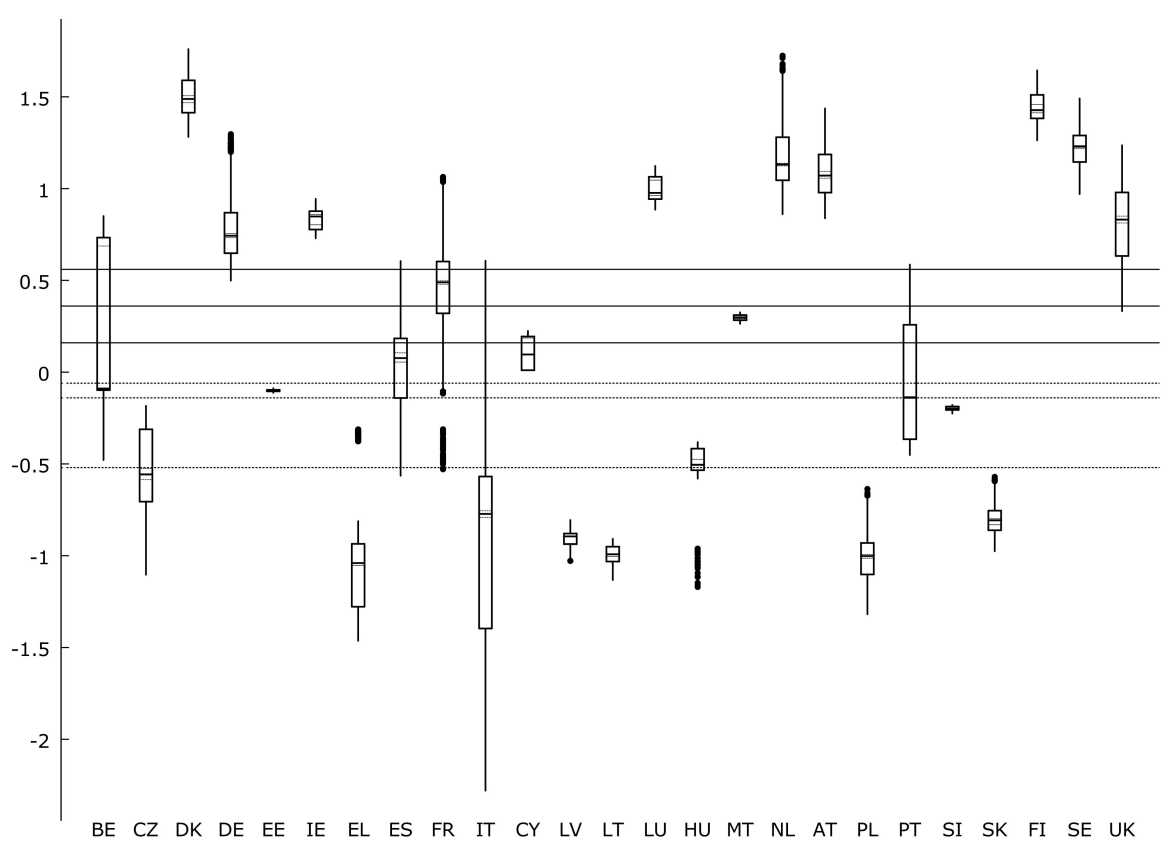

Figure A1. Distribution of $Q_{i, t}$ values over the 2000-2006 programming period into quartiles, highlighting the median value (solid line) and CI bounds of the mean (dash line). Lines extending vertically (whiskers) indicate variability outside the upper and lower quartiles, and any point outside those lines (whiskers) is considered an outlier. $Q_{i, t}$ values above long horizontal solid line condition positive and insignificant growth outcomes of the CP. $Q_{i, t}$ values below long horizontal dash line condition negative and significant growth outcomes of the CP. See Table 3 in the main text for a specific threshold level.

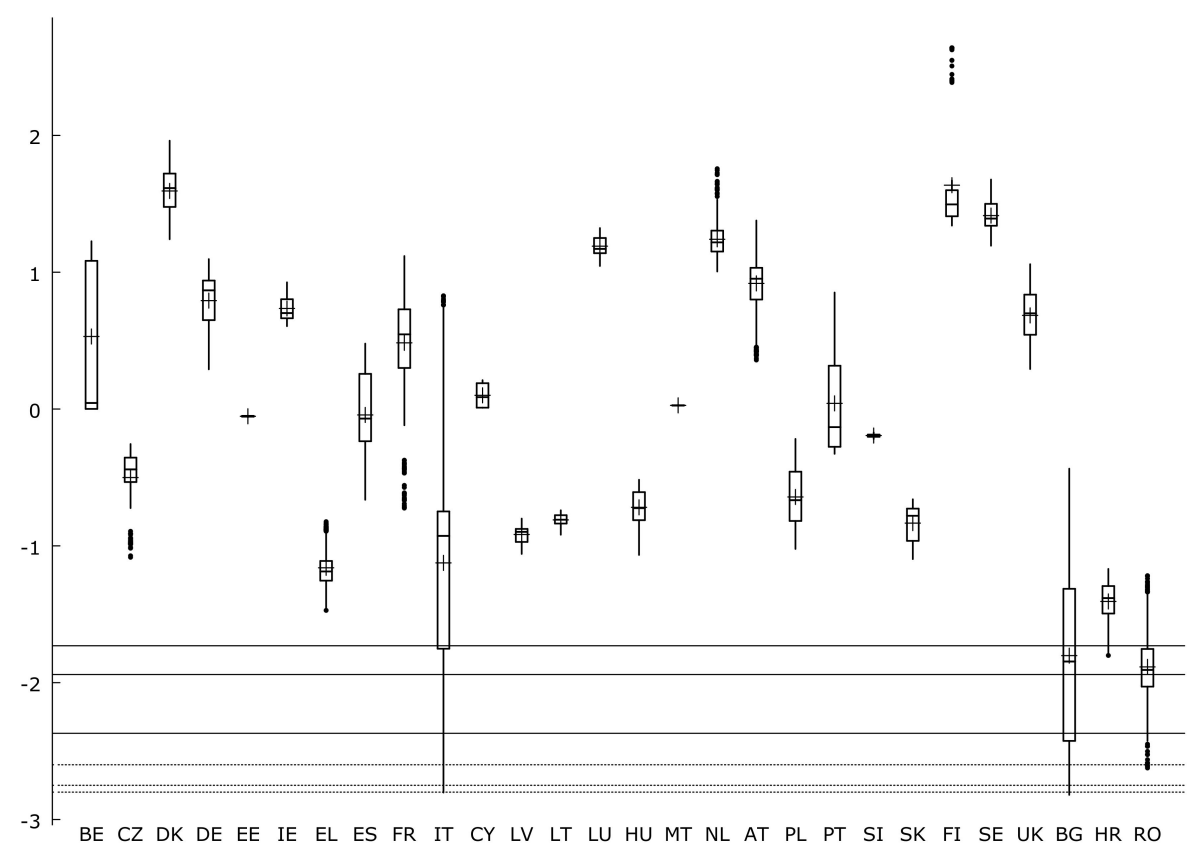

Figure A2. Distribution of $Q_{i, t}$ values over the 2007-2013 programming period into quartiles, highlighting the median value (solid line) and the mean (plus). Lines extending vertically (whiskers) indicate variability outside the upper and lower quartiles, and any point outside those lines (whiskers) is considered an outlier. $Q_{i, t}$ values above long horizontal solid line condition positive and significant growth outcomes of the CP. $Q_{i, t}$ values below long horizontal dash line condition negative and insignificant growth outcomes of the CP. See Table 3 in the main text for a specific threshold level. 
Appendix C.4

Table A5. Control variables.

\begin{tabular}{|c|c|c|c|c|c|c|}
\hline \multirow[t]{2}{*}{ Short Name } & \multirow[t]{2}{*}{$\begin{array}{l}\text { Full Name, Description and } \\
\text { Source of Data }(1)\end{array}$} & \multirow[t]{2}{*}{$\begin{array}{l}\text { Measurement } \\
\text { Unit }\end{array}$} & \multicolumn{2}{|c|}{$\begin{array}{l}\text { The NUTS Level at } \\
\text { Which Data Is } \\
\text { Available }\end{array}$} & \multicolumn{2}{|c|}{$\begin{array}{c}\text { Included in the Estimation } \\
\text { with the Dependent } \\
\text { Variable }\end{array}$} \\
\hline & & & 2 & 3 & $\begin{array}{l}\text { Economic } \\
\text { Growth }\end{array}$ & $\begin{array}{l}\text { Productivity } \\
\text { Growth }\end{array}$ \\
\hline POP & $\begin{array}{l}\text { Average annual population by } \\
\text { NUTS } 3 \text { regions } \\
\text { (nama_10r_3popgdp) }\end{array}$ & $\begin{array}{l}\text { Thousand } \\
\text { persons }\end{array}$ & $x$ & $x$ & $x$ & \\
\hline IGDP & $\begin{array}{l}\text { Investment calculated as the } \\
\text { ratio between Gross fixed } \\
\text { capital formation by NUTS } 2 \\
\text { regions (nama_10r_2gfcf) and } \\
\text { Gross domestic product (GDP) } \\
\text { at current market prices by } \\
\text { NUTS } 2 \text { regions } \\
\text { (nama_10r_2gdp). }\end{array}$ & $\%$ & $x$ & & $x$ & \\
\hline IWRK & $\begin{array}{l}\text { Investment calculated per } \\
\text { worker, as the ratio between } \\
\text { Gross fixed capital formation } \\
\text { by NUTS } 2 \text { regions } \\
\text { (nama_10r_2gfcf) and } \\
\text { Employment (thousand } \\
\text { persons) by NUTS } 3 \text { regions } \\
\text { (nama_10r_3empers). }\end{array}$ & Euro & $x$ & & & $x$ \\
\hline PEDUC & $\begin{array}{l}\text { Primary education, i.e., } \\
\text { proportion of } 25-64 \text { years-old } \\
\text { population with less than } \\
\text { primary, primary and lower } \\
\text { secondary education (levels } \\
\text { 0-2). Data retrieved from } \\
\text { Population aged } 25-64 \text { by } \\
\text { educational attainment level, } \\
\text { sex and NUTS } 2 \text { regions (\%) } \\
\text { (edat_lfse_04). }\end{array}$ & $\%$ & $x$ & & $x$ & $x$ \\
\hline TEDUC & $\begin{array}{l}\text { Tertiary education, i.e., the } \\
\text { proportion of } 25-64 \text { years-old } \\
\text { population with tertiary } \\
\text { education (levels 5-8). Data } \\
\text { retrieved from Population aged } \\
25-64 \text { by educational } \\
\text { attainment level, sex and NUTS } \\
2 \text { regions (\%) (edat_lfse_04). }\end{array}$ & $\%$ & $x$ & & $X$ & $x$ \\
\hline HTEC & $\begin{array}{l}\text { Employment in } \\
\text { High-technology sectors } \\
\text { (high-technology } \\
\text { manufacturing and } \\
\text { knowledge-intensive } \\
\text { high-technology services). Data } \\
\text { for 2000-2006 retrieved from } \\
\text { Employment in technology and } \\
\text { knowledge-intensive sectors by } \\
\text { NUTS } 2 \text { regions and sex } \\
\text { (1994-2008, NACE Rev. 1.1) } \\
\text { (htec_emp_reg). For 2007-2013 } \\
\text { from Employment in } \\
\text { technology and } \\
\text { knowledge-intensive sectors by } \\
\text { NUTS } 2 \text { regions and sex (from } \\
\text { 2008 onwards, NACE Rev. 2) } \\
\text { (htec_emp_reg2). }\end{array}$ & $\begin{array}{l}\text { Percentage } \\
\text { of total } \\
\text { employment }\end{array}$ & $x$ & & $x$ & \\
\hline
\end{tabular}


Table A5. Cont.

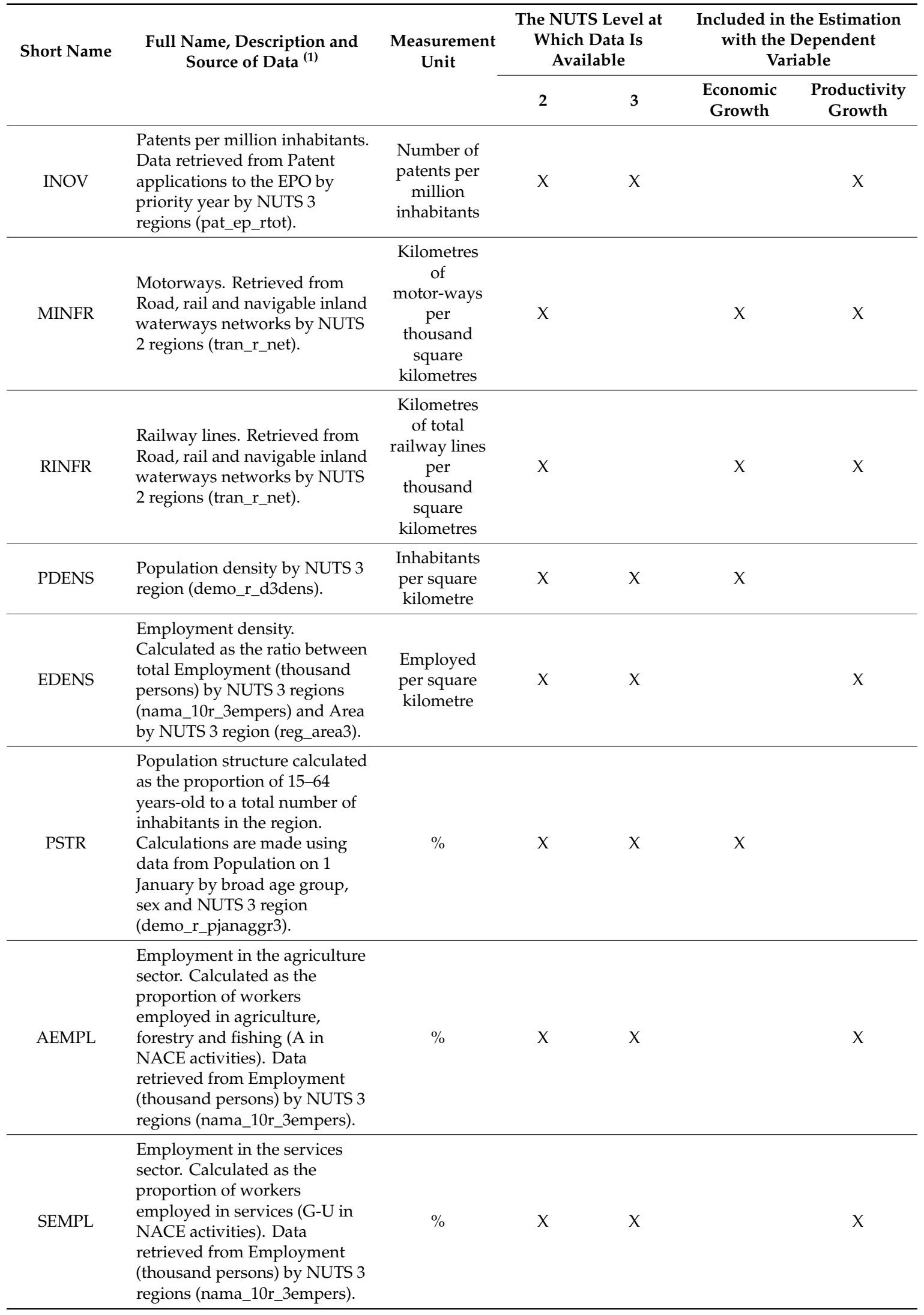


Table A5. Cont.

\begin{tabular}{|c|c|c|c|c|c|c|}
\hline \multirow[t]{2}{*}{ Short Name } & \multirow[t]{2}{*}{$\begin{array}{l}\text { Full Name, Description and } \\
\text { Source of Data }{ }^{(1)}\end{array}$} & \multirow[t]{2}{*}{$\begin{array}{l}\text { Measurement } \\
\text { Unit }\end{array}$} & \multicolumn{2}{|c|}{$\begin{array}{c}\text { The NUTS Level at } \\
\text { Which Data Is } \\
\text { Available }\end{array}$} & \multicolumn{2}{|c|}{$\begin{array}{c}\text { Included in the Estimation } \\
\text { with the Dependent } \\
\text { Variable }\end{array}$} \\
\hline & & & 2 & 3 & $\begin{array}{l}\text { Economic } \\
\text { Growth }\end{array}$ & $\begin{array}{l}\text { Productivity } \\
\text { Growth }\end{array}$ \\
\hline AGVA & $\begin{array}{l}\text { Agriculture gross value added. } \\
\text { Calculated as the proportion of } \\
\text { GVA created in agriculture, } \\
\text { forestry and fishing (A in } \\
\text { NACE activities). Data } \\
\text { retrieved from Gross value } \\
\text { added at basic prices by NUTS } \\
3 \text { regions (nama_10r_3gva). }\end{array}$ & $\%$ & $X$ & $x$ & $X$ & \\
\hline SGVA & $\begin{array}{l}\text { Services gross value added. } \\
\text { Calculated as the proportion of } \\
\text { GVA created in services (G-U in } \\
\text { NACE activities). Data } \\
\text { retrieved from Gross value } \\
\text { added at basic prices by NUTS } \\
3 \text { regions (nama_10r_3gva). }\end{array}$ & $\%$ & $X$ & $x$ & $x$ & \\
\hline SI & $\begin{array}{l}\text { Regional to national per capita } \\
\text { GDP ratio used to proxy spatial } \\
\text { interdependence }\end{array}$ & $\%$ & $x$ & $X$ & $x$ & $x$ \\
\hline
\end{tabular}

(1) All data collected from Eurostat.

\section{References}

1. Ciani, E.; de Blasio, G. European structural funds during the crisis: Evidence from Southern Italy. IZA J. Labour Policy 2015, 4, 1-31. [CrossRef]

2. Di Cataldo, M. The impact of EU Objective 1 funds on regional development: Evidence from the UK and the prospect of Brexit. J. Reg. Sci. 2017, 57, 814-839. [CrossRef]

3. Becker, S.O.; Egger, P.; von Ehrlich, M. Effects of EU Regional Policy: 1989-2013. Reg. Sci. Urban Econ. 2018, 69, 143-152. [CrossRef]

4. Coppola, G.; Destefanis, S. Structural Funds and Regional Convergence: Some Sectoral Estimates for Italy. In Geographical Labor Market Imbalances. AIEL Series in Labour Economics; Mussida, C., Pastore, F., Eds.; Springer: Berlin/Heidelberg, Germany, 2015.

5. Dotti, N.F. Unwritten Factors Affecting Structural Funds: The Influence of Regional Political Behaviours on the Implementation of EU Cohesion Policy. Eur. Plan. Stud. 2016, 24, 530-550. [CrossRef]

6. Pontarollo, N. Does Cohesion Policy affect regional growth? New evidence from a semi-parametric approach. In EU Cohesion Policy; Bachtler, J., Berkowitz, P., Hardy, S., Muravska, T., Eds.; Routledge: Abingdon, UK, 2017; pp. 93-108.

7. Pinho, C.; Varum, C.; Antunes, M. Structural Funds and European Regional Growth: Comparison of Effects among Different Programming Periods. Eur. Plan. Stud. 2015, 23, 1302-1326. [CrossRef]

8. Pinho, C.; Varum, C.; Antunes, M. Under What Conditions Do Structural Funds Play a Significant Role in European Regional Economic Growth? Some Evidence from Recent Panel Data. J. Econ. Issues 2015, 49, 749-771. [CrossRef]

9. Maynou, L.; Saez, M.; Kyriacou, A.; Bacaria, J. The Impact of Structural and Cohesion Funds on Eurozone Convergence, 1990-2010. Reg. Stud. 2016, 50, 1127-1139. [CrossRef]

10. Pellegrini, G.; Cerqua, A. Measuring the impact of intensity of treatment using RDD and covariates: The case of Structural Funds. In Proceedings of the 57th RSA Annual Conference, Bocconi University, Milan, Italy, 20-22 October 2016.

11. Gagliardi, L.; Percoco, M. The impact of European Cohesion Policy in urban and rural regions. Reg. Stud. 2017, 51, 857-868. [CrossRef] 
12. Piętak, L. Did Structural Funds Affect Economic Growth and Convergence Across Regions? Spanish Case in the Years 1989-2016. INE PAN Work Pap. Ser. 2018, p. 44. Available online: http://inepan.pl/wp-content/ uploads/2016/07/working-papers-44-Hiszpania-Pietak.pdf. (accessed on 20 November 2019).

13. Pellegrini, G.; Busillo, T.; Muccigrosso, T.; Tarola, O.; Terribile, F. Measuring the Impact of the European Regional Policy on Economic Growth: A Regression Discontinuity Design Approach. Pap. Reg. Sci. 2013, 92, 217-233. [CrossRef]

14. Di Cataldo, M.; Monastiriotis, V. An Assessment of EU Cohesion Policy in the UK Regions: Direct Effects and the Dividends of Targeting; LEQS-LSE ‘Europe in Question' Discussion Paper Series 135; European Institute, LSE: London, UK, 2018; Available online: http://www.lse.ac.uk/European-institute/Assets/Dokuments/LEQSDiscussion-Papers/LEQSPaper135.pdf (accessed on 20 November 2019).

15. Kutan, A.M.; Yigit, T.M. European integration, productivity growth and real convergence. Eur. Econ. Rev. 2007, 51, 1370-1395. [CrossRef]

16. Kyriacou, A.P.; Roca-Sagales, O. The Impact of EU Structural Funds on Regional Disparities within Member States. Environ. Plan. C Politics Space 2012, 30, 267-281. [CrossRef]

17. Becker, S.O.; Egger, P.; von Ehrlich, M. Absorptive Capacity and the Growth and Investment Effects of Regional Transfers: Regression Discontinuity Design with Heterogeneous Treatment Effects. Am. Econ. J. Econ. Policy 2013, 5, 29-77. [CrossRef]

18. Rodríguez-Pose, A.; Garcilazo, E. Quality of Government and the Returns of Investment: Examining the Impact of Cohesion Expenditure in European Regions. Reg. Stud. 2015, 49, 1274-1290. [CrossRef]

19. Arbolino, R.; Boffardi, R. The Impact of Institutional Quality and Efficient Cohesion Investments on Economic Growth Evidence from Italian Regions. Sustainability 2017, 9, 1432. [CrossRef]

20. Jones, G.; Potrafke, N. Human capital and national institutional quality: Are TIMSS, PISA, and national average IQ robust predictors? Intelligence 2014, 46, 148-155. [CrossRef]

21. Fakher, A. Quality of institutions and integration in the world economy: Applied study on Egypt. J. Econ. Bus. 2014, 17, 69-96.

22. Ellis, J.A.; Smith, J.D.; White, R.M. Corruption and Corporate Innovation. Forthcom. J. Financ. Quant. Anal. 2015. Available online: http://dx.doi.org/10.2139/ssrn.2862128 (accessed on 20 August 2019).

23. Jude, C.; Levieuge, G. Growth Effect of Foreign Direct Investment in Developing Economies: The Role of Institutional Quality. World Econ. 2016, 40, 715-742. [CrossRef]

24. Boudreaux, C.J. Institutional quality and innovation: Some cross-country evidence. J. Entrep. Public Policy 2017, 6, 26-40. [CrossRef]

25. Alvarez, I.C.; Barbero, J.; Rodriguez-Pose, A.; Zofio, J.L. Does institutional quality matter for trade? Institutional conditions in a sectoral trade framework. World Dev. 2018, 103, 72-87. [CrossRef]

26. Rodríguez-Pose, A.; Novak, K. Learning processes and economic returns in European Cohesion Policy. Investig. Reg. 2013, 25, 7-26.

27. Brambor, T.; Clark, W.; Golder, M. Understanding Interaction Models: Improving Empirical Analyses. Political Anal. 2006, 14, 63-82. [CrossRef]

28. Falk, M.; Sinabell, F. The Effectiveness of Objective 1 Structural Funds in the EU 15: New Empirical Evidence from NUTS 3 Regions. In WIFO Working Papers 310; Austrian Institute of Economic Research (WIFO): Vienna, Austria, 2008; Available online: https://www.econstor.eu/bitstream/10419/128866/1/wp_310.pdf (accessed on 20 August 2019).

29. Fratesi, P.; Perucca, G. Territorial capital and the effectiveness of cohesion policies: An assessment for CEE Regions. Investig. Reg. J. Reg. Res. 2014, 29, 165-191.

30. Solow, R.M. A contribution to the theory of economic growth. Q. J. Econ. 1956, 70, 65-94. [CrossRef]

31. Swan, T.W. Economic Growth and Capital Accumulation. Econ. Rec. 1956, 32, 334-361. [CrossRef]

32. Romer, P.M. Endogenous technological change. J. Political Econ. 1990, 98, S71-S102. [CrossRef]

33. Romer, P.M. The Origins of Endogenous growth. J. Econ. Perspect. 1994, 8, 3-22. [CrossRef]

34. Nguyen, C.T.; Trinh, L.T. The impact of public investment on private investment and economic growth: Evidence from Vietnam. J. Asian Bus. Econ. Stud. 2018, 25, 15-32. [CrossRef]

35. Fujita, M.; Krugman, P.; Venables, A.J. The Spatial Economy: Cities, Regions and International Trade; MIT Press: Cambridge, MA, USA, 1999.

36. Bouayad-Agha, S.; Turpinn, N.; Védrine, L. Fostering the Development of European Regions: A Spatial Dynamic Panel Data Analysis of the Impact of Cohesion Policy. Reg. Stud. 2013, 47, 1573-1593. [CrossRef] 
37. Gómez-García, J.; Enguix, M.D.R.M.; Gómez-Gallego, J.C. Estimations of the efficiency of structural funds: A parametric and nonparametric approach. Appl. Econ. 2012, 44, 3935-3954. [CrossRef]

38. Host, A.; Zaninović, V.; Krešimir, P. Cohesion Policy Instruments and Economic Growth: Do Institutions Matter? Ekon. Misao Praksa 2017, 2, 541-559.

39. Crescenzi, R.; Giua, M. The EU Cohesion Policy in Context: Regional Growth and the Influence of Agricultural and Rural Development Policies; LSE ‘Europe in Question' Discussion Paper Series 2014, 85/2014, 1-50; University of Pittsburgh: Pittsburgh, PA, USA; Available online: http://aei.pitt.edu/93663/ (accessed on 20 November 2019).

40. Kyriacou, A.P. Ethnic segregation and the quality of government: The importance of regional diversity. Const. Political Econ. 2012, 23, 166-180. [CrossRef]

41. Eberle, J.; Brenner, T. More bucks, more growth, more justice? The effects of regional structural funds on regional economic growth and convergence in Germany. Work. Pap. Innov. Space. 16 January 2016. Available online: https://www.econstor.eu/handle/10419/147971 (accessed on 20 November 2019).

42. Dias, J.; Tebaldi, E. Institutions, Human Capital, and Growth: The Long-run Institutional Mechanism. Struct. Chang. Econ. Dyn. 2012, 23, 300-312. [CrossRef]

43. Bouzahzah, M.; Simplice, S.A.; Jellal, M. Institutional Governance, Education and Growth. Theor. Econ. Lett. 2016, 6, 131-137. [CrossRef]

44. Wang, Y.; Cheng, L.; Wang, H.; Li, L. Institutional quality, financial development and OFDI. Pac. Sci. Rev. 2014, 16, 127-132. [CrossRef]

45. Ma, J.; Lu, Y. Free Trade or Protection: A Literature Review on Trade Barriers. Res. World Econ. 2011, 2, 69-70. [CrossRef]

46. Anderson, J.E.; Marcouiller, D. Insecurity and the pattern of trade: An empirical investigation. Rev. Econ. Stat. 2002, 84, 342-352. [CrossRef]

47. Estrada, G.; Park, D.; Ramayandi, A. Financial Development, Financial openness, and Economic growth. Adb Econ. Work. Pap. Ser. 2015, p. 442. Available online: https://papers.ssrn.com/sol3/papers.cfm?abstract_ $\mathrm{id}=2707518$ (accessed on 20 August 2019).

48. Benáček, V.; Lenihan, H.; Andresso-O'Callaghan, B.; Michalíková, E. Political Risk, Institutions and Foreign Direct Investment: How Do They Relate in Various European Countries? World Econ. 2013, 37, 625-653. [CrossRef]

49. Aziz, O.G. Institutional quality and FDI inflows in Arab economies. Financ. Res. Lett. 2018, 25, 111-123. [CrossRef]

50. Arpaia, A.; Mourre, G. Institutions and Performance in European Labour Markets: Taking a gresh look at evidence. Econ. Pap. 2009, 391. [CrossRef]

51. Grigoli, F.; Mills, Z. Institutions and Public investment: An empirical analysis. Econ. Gov. 2014, 15, 131-153. [CrossRef]

52. Alesina, A.; Zhuravskaya, E. Segregation and the quality of government in a cross-section of countries. Am. Econ. Rev. 2011, 101, 1872-1911. [CrossRef]

53. Henderson, J.V.; Wang, H.G. Urbanization and city growth: The role of Institutions. Reg. Sci. Urban Econ. 2007, 37, 283-313. [CrossRef]

54. Dellmuth, L.M.; Schraff, D.; Stoffel, M.F. Distributive Politics, Electoral Institutions and European Structural and Investment Funding: Evidence from Italy and France. J. Common Mark. Stud. 2017, 55, 275-293. [CrossRef]

55. Olson, M. The Logic of Collective Action: Public Goods and the Theory of Groups; Harvard University Press: Cambridge, MA, USA; London, UK, 1965.

56. Beugelsdijk, M.S.; Eijffinger, S.C.W. The effectiveness of structural policy in the European Union: An empirical analysis for the EU-15 in 1995-2001. J. Common Mark. Stud. 2005, 43, 37-51. [CrossRef]

57. Mo, P.H. Corruption and Economic Growth. J. Comp. Econ. 2001, 29, 66-70. [CrossRef]

58. Cerqua, A.; Pellegrini, G. Are we spending too much to grow? The case of Structural Funds. J. Reg. Sci. 2018, 58, 535-563. [CrossRef]

59. Wright, G. Linear Models for Evaluating Conditional Relationship. Am. J. Political Sci. 1976, 20, 349-373. [CrossRef]

60. Friedrich, R. In Defense of Multiplicative Terms in Multiple Regression Equations. Am. J. Political Sci. 1982, 26, 797-833. [CrossRef] 
61. Leona, A.; West, S. Multiple Regression: Testing and Interpreting Interactions; Sage: London, UK, 1991.

62. Rodríguez-Pose, A.; Fratesi, U. Between Development and Social Policies: The Impact of European Structural Funds in Objective 1 Regions. Reg. Stud. 2004, 38, 97-113. [CrossRef]

63. Butkus, M.; Cibulskiene, D.; Maciulyte-Sniukiene, A.; Matuzeviciute, K. What Is the Evolution of Convergence in the EU? Decomposing EU Disparities up to NUTS 3 Level. Sustainability 2018, 10, 1552. [CrossRef]

64. Florio, M.; Moretti, L. The Effect of Business Support on Employment in Manufacturing: Evidence from the European Union Structural Funds in Germany, Italy and Spain. Eur. Plan. Stud. 2014, 22, 1802-1823. [CrossRef]

65. Mohl, P.; Hagen, T. Does EU cohesion policy promote growth? Evidence from regional data and alternative econometric approaches. Zew Discuss. Pap. 2008, 8-86. [CrossRef]

66. Wostner, P.; Šlander, S. The effectiveness of EU cohesion policy revisited: Are EU funds really additional? Eur. Policies Res. Cent. 2009, 69, 1-26.

67. Becker, S.O.; Egger, P.; von Ehrlich, M.; Fenge, R. Going NUTS-The effect of EU structural funds on regional performance. J. Public Econ. 2010, 94, 578-590. [CrossRef]

68. Mohl, P.; Hagen, T. Does EU structural funds promote regional growth? New evidence from various panel data approaches. Reg. Sci. Urban Econ. 2010, 40, 353-365. [CrossRef]

69. Varga, J.; Veld, J. A Model-Based Analysis of the Impact of Cohesion Policy Expenditure 2000-06: Simulations with QUEST III endogenous R\&D model. Econ. Model. 2010, 28, 647-663. [CrossRef]

70. Accetturo, A.; de Blasio, G.; Ricci, L. A tale of unwanted outcome: Transfers and local endowments of trust and cooperation. J. Econ. Behav. Organ. 2014, 102, 74-89. [CrossRef]

71. European Commission. Measuring the impact of Structural and Cohesion Funds using regression discontinuity design in EU27 in the period 1994-2011, Ex post evaluation of Cohesion Policy programmes 2007-2013, focusing on the European Regional Development Fund (ERDF) and the Cohesion Fund (CF). Final technical Report, Work Package 14c—Tasks 2 and 3. 2016. Available online: https://ec.europa.eu/ regional_policy/sources/docgener/evaluation/pdf/expost2013/wp14c_task1_final_report_en.pdf (accessed on 15 July 2019).

72. Bondonio, D.; Pellegrini, G. Macro-economic effects of cohesion policy funding in 2007-2013 Executive Summary. Work Package 14c: Regression discontinuity design. Work Package 14d: Propensity score matching. Ex post evaluation of Cohesion Policy programmes 2007-2013, focusing on the European Regional Development Fund (ERDF) and the Cohesion Fund (CF). European Commission. Luxembourg: Publications Office of the European Union. 2016. Available online: https://ec.europa.eu/regional_policy/sources/docgener/ evaluation/pdf/expost2013/wp14c_d_executive_summary_en.pdf (accessed on 15 July 2019).

73. SWECO. Final Report-ERDF and CF Regional Expenditure Contract. 2008. 2007.CE.16.0.AT.036. Available online: https://ec.europa.eu/regional_policy/sources/docgener/evaluation/pdf/expost2006/expenditure_final. pdf (accessed on 15 July 2019).

74. Ciffolilli, A.; Condello, S.; Pompili, M.; Roemish, R.; Geography of Expenditure. Final Report. Work Package 13. Ex post evaluation of Cohesion Policy programmes 2007-2013, focusing on the European Regional Development Fund (ERDF) and the Cohesion Fund (CF). 2015. Available online: https://ec.europa. eu/regional_policy/sources/docgener/evaluation/pdf/expost2013/wp13_final_report_en.pdf (accessed on 15 July 2019).

75. Charron, N.; Lapuente, V.; Rothstein, B. (Eds.) Measuring the Quality of Government and Subnational Variation. Report for the European Commission Directorate-General Regional Policy, Directorate Regional Policy; Quality of Quality of Government and Returns of Investment: Cohesion Expenditure in European Regions 1289 Government Institute, Department of Political Science, University of Gothenburg: Gothenburg, Sweden, 2010; Available online: http://ec.europa.eu/regional_policy/sources/docgener/studies/pdf/2010_government_1.pdf (accessed on 15 July 2019).

76. Charron, N.; Dijkstra, L.; Lapuente, V. Regional governance matters: Quality of government within European union member states. Reg. Stud. 2014, 48, 68-90. [CrossRef]

(C) 2020 by the authors. Licensee MDPI, Basel, Switzerland. This article is an open access article distributed under the terms and conditions of the Creative Commons Attribution (CC BY) license (http://creativecommons.org/licenses/by/4.0/). 